WIDER Working Paper 2016/61

\title{
The power to choose
}

Gender balance of power and intra-household educational spending in India

Christophe J. Nordman ${ }^{1}$ and Smriti Sharma ${ }^{2}$

May 2016 
Abstract: We assess the effect of female bargaining power on the share of educational expenditures in the household budget in India. We augment the collective household model by endogenizing female bargaining power and use a three-stage least squares approach to simultaneously estimate female bargaining power, per capita household expenditure and budget share of education. Our key results are: (i) female bargaining power has a positive and significant effect on the household budget share of educational spending; (ii) this bargaining power is associated positively (negatively) with education spending in urban (rural) areas; (iii) female bargaining power has a uniformly positive effect on educational expenditure of girls in urban areas among all caste groups, but the observed negative association in rural areas appears to be driven by one of the lower caste groups; and (iv) a pro-male bias exists in educational spending for all age groups, with some differentiation by location and caste.

Keywords: collective household model, female bargaining power, gender bias, education, India JEL classification: D13, C31, J16, I25

Tables: at the end of the paper.

Acknowledgements: We are grateful for support from UNU-WIDER. An earlier draft of this paper has benefited from comments from Pushkar Maitra, Vegard Iversen, Véronique Gille, and participants at the UNU-WIDER workshop on 'Discrimination and Affirmative Action' and the 2016 India Human Development Survey User Conference. Youna Lanos provided excellent research assistance. All remaining errors are our own.

\footnotetext{
${ }^{1}$ IRD, DIAL, and IZA, Paris, France; corresponding author: nordman@dial.prd.fr; ${ }^{2}$ UNU-WIDER, Helsinki, Finland.

This study has been prepared within the UNU-WIDER project on 'Discrimination and Affirmative Action: What have we learnt so far?', which is part of a larger research project on 'Disadvantaged Groups and Social Mobility'.

Copyright (C) UNU-WIDER 2016

Information and requests: publications@wider.unu.edu

ISSN 1798-7237 ISBN 978-92-9256-104-8
}

Typescript prepared by Ayesha Chari.

The United Nations University World Institute for Development Economics Research provides economic analysis and policy advice with the aim of promoting sustainable and equitable development. The Institute began operations in 1985 in Helsinki, Finland, as the first research and training centre of the United Nations University. Today it is a unique blend of think tank, research institute, and UN agency_providing a range of services from policy advice to governments as well as freely available original research.

The Institute is funded through income from an endowment fund with additional contributions to its work programme from Denmark, Finland, Sweden, and the United Kingdom.

Katajanokanlaituri 6 B, 00160 Helsinki, Finland

The views expressed in this paper are those of the author(s), and do not necessarily reflect the views of the Institute or the United Nations University, nor the programme/project donors. 
Achieving gender equality in educational inputs and outcomes has been recognized as a key policy objective in the United Nations' Millennium Development Goals and now also in the 2030 Sustainable Development Agenda. In recent decades, empowering women has also been acknowledged not only as an important human right but also as a way to confer benefits to households, and thereby contribute to overall economic development. This is also the view echoed by the World Bank (2012) and Duflo (2012).

In this paper, our objective is to understand how gender matters for intra-household decisionmaking processes. More specifically, we ask the following three questions: (i) Does the bargaining power of women affect the household's budget share devoted to education? (ii) Does the intra-household allocation of educational expenditure among sons and daughters depend on female bargaining power? (iii) Do these effects vary by caste of households? We answer these using recently available data from the large-scale nationally representative India Human Development Survey 2011-12 (IHDS-II; see Desai et al. 2011-12).

An increase in female bargaining power and autonomy has been linked to greater allocation of resources in favour of children in the household. For instance, Duflo (2003) examines the effect of pensions received by elderly women and men in South Africa on investment in girls relative to boys. She estimates that girls' weight-for-height and height-for-age improved when grandmothers were beneficiaries, but finds no evidence of gender differences when grandfathers were the recipients of pensions. Reggio (2011) finds that an increase in maternal bargaining power is associated with fewer hours of work for daughters in Mexico. The underlying explanation proposed for such findings is that women tend to be more altruistic than men and are therefore inclined to make decisions that benefit children's welfare and, thus, overall household welfare. Using an artefactual field experiment, Dasgupta and Mani (2015) focus on eliciting the role of entitlements on altruistic consumption choices among husbands and wives. They find that wives are more likely to choose the joint household consumption bundle whereas husbands are more likely to choose a private consumption good, irrespective of the way their economic resources are earned, thereby suggesting greater altruism on the part of women. ${ }^{1}$

In terms of the literature examining education-related outcomes, Rangel (2006), using a legal change in alimony rights in Brazil, shows that more decision-making power in the hands of women increases children's school enrolment, especially that of first-born girls. Specifically, in terms of educational expenditures, using data from four countries (Bangladesh, Indonesia, Ethiopia, and South Africa), Quisumbing and Maluccio (2003) find that female bargaining power as defined by a woman's assets at marriage increases the share of household expenditures on children's education, but whether boys or girls benefit more differs substantially across countries, highlighting the relevance of cultural factors. For instance, in Bangladesh, mother's schooling and assets have a positive effect on girls' education. In Ethiopia, on the other hand, the mother's asset ownership reduces investments in daughter's education but leads to increases for boys. Menon et al. (2014) find that land titling solely in favour of women in Viet Nam resulted in an increase in school enrolment, along with a host of other positive effects for children's human capital. Specifically, for India, Afridi (2010) investigates the effect of female autonomy on children's educational outcomes, as measured by grade attainment to find that households with more educated and autonomous mothers exhibit lesser bias against girls' schooling. Although an increase in both paternal and maternal education is associated with a larger effect on daughter's

\footnotetext{
${ }^{1}$ See Doss (2013) for an overview.
} 
attainment, the maternal education level matters more for the gender gap in schooling. Alfano et al. (2011) study the effect of female autonomy on school starting age of children using data for three states in India (Andhra Pradesh, Kerala, and Uttar Pradesh) and find it to be a significant positive determinant in only Uttar Pradesh.

The existence of a gender gap in educational expenditures in India is not a new finding. In fact, it is intricately linked with and forms a part of the overall pattern of gender inequality and son preference that characterizes countries such as India and China. ${ }^{2}$ Using the Engel curve approach, Subramanian and Deaton (1991) find a weak pro-male bias in the age group of 10-14 years in rural Maharashtra. ${ }^{3}$ Lancaster et al. (2008) find a pro-male bias in the age group of 11-16 years in the rural areas of the states of Bihar and Maharashtra. Kingdon (2005) discusses that any gender bias in educational expenditures can be on account of two decisions: one, the (binary) decision to enrol sons and daughters; and two, conditional on enrolment of sons and daughters, how much to spend on their education. Using a hurdle model that takes these two decisions into account, Azam and Kingdon (2013) find a greater pro-male bias in enrolment decisions in the age group of 15-19 years but a greater bias in expenditure decisions in the age group of 10-14 years. ${ }^{4}$ Zimmerman (2012), using both hurdle models and the Engel curve method, also finds discrimination against girls in educational expenditures to be increasing in age.

Possible differentiation of the effect of female bargaining power by caste is worth investigating. ${ }^{5}$ Since Scheduled Caste (SC) women have historically worked outside the home, even though typically in low-paying occupations, it has been argued that the resulting income and the independence gave rise to a culture in which these women were relatively assertive within their households, enjoyed greater financial autonomy and greater control over household resources (Chakravarti 1993; Kapadia 1997; Mencher 1988). Similarly, within Scheduled Tribes (STs), despite regional and tribe-specific heterogeneity, attitudes towards women are generally more liberal, and, in some northeastern Indian states, there is also a presence of matrilineal tribes (see Mitra 2008 and references therein). In contrast, among the upper castes, irrespective of their economic status, maintaining ritual purity has been an important concern, which results in greater restrictions on the mobility, decision-making, and labour force participation of women. For instance, Eswaran et al. (2013) find that controlling for wealth, women's time allocated to market work relative to that of men declines as one moves up the caste hierarchy.

In this paper, we extend the collective household model (Bourguignon et al. 1993; Browning and Chiappori 1998) by taking into account Basu's (2006) critique that the welfare weights assigned to household members are not exogenous to the household, as assumed by these models.

\footnotetext{
${ }^{2}$ See Jayachandran (2015) for a discussion of cultural factors (e.g. patrilocality, patrilineality, dowry system, reliance on sons for support during old age) that perpetuate gender inequality, with specific reference to India and China.

3 The Engel curve approach regresses the household budget share of the good in question on log of per capita expenditure, log of household size, shares of different age-sex groups, and other household characteristics.

${ }^{4}$ The hurdle model is a two-step estimation whose first step estimates the likelihood of a household deciding to spend money on children's education. The second step is an ordinary least square (OLS) regression of educational spending for the subset of households that have positive levels of spending, referred to as a conditional OLS.

${ }^{5}$ The caste system in India is historically rooted, and places individuals into hierarchical groups that are hereditary, mostly endogamous, and occupation-specific. The 'untouchables', also referred to as Scheduled Castes (SCs), make up the bottom rank of this hierarchy and were subjected to segregation and had limited access to public goods on account of 'pollution' associated with them. The indigenous tribes (categorized as Scheduled Tribes, STs) have been geographically isolated and, owing to their distinct culture and norms, tend to be socially excluded from mainstream Indian society. In addition to the SCs and STs, there are the Other Backward Classes (OBCs). This group is socially and educationally backward but not stigmatized like the other groups.
} 
Instead, he contends that the balance of power among household members is simultaneously determined with other household characteristics. To account for the endogeneity of female bargaining power (as proxied by the share of female wage income in the household's total wage income) and household economic status (as proxied by per capita expenditure), we simultaneously estimate equations for female bargaining power, log of per capita household expenditure, and budget share of education using a three-stage least squares (3SLS) methodology. The empirical methodology is similar to that used by Lancaster et al. (2006). Some of the key differences between our analysis and that of Lancaster et al. (2006) are: first, their paper, using Indian data, is concerned with the effect of male bargaining power on expenditure patterns covering various goods, whereas we focus solely on the effect of female bargaining on educational expenditures and are further able to study its impact on gender-specific expenditures, as facilitated by our data; second, acknowledging that caste is a major aspect of one's social identity in India, we also comment on how this relationship is mediated by caste; finally, they study only three states in India whereas we use nationally representative data covering all states, thereby providing more generalizable results for a recent time period.

Our key results are: (i) female bargaining power has a positive and significant effect on the household budget share of educational spending; (ii) there are location-based differences such that female bargaining power is associated positively (negatively) with education spending in urban (rural) areas; (iii) female bargaining power has a uniformly positive effect on educational expenditure of girls in urban areas among all caste groups, but the observed negative association in rural areas appears to be driven by the sample of Other Backward Classes (OBCs); and (iv) a pro-male bias exists in educational spending for all age groups, with some differentiation by location and caste.

The rest of this paper is organized as follows. Section 2 describes the methodology used. Section 3 discusses the data. Section 4 lays out the summary statistics and results. Section 5 concludes.

\section{$2 \quad$ Methodology}

Typically, the collective household model (Bourguignon et al. 1993; Browning and Chiappori 1998) forms the theoretical foundation to answer questions pertaining to intra-household allocation. However, a potential drawback of such a model is that the welfare weight assigned to each income earner is assumed to be exogenous to the household's decision-making. Basu (2006) critiques this assumption, and proposes a framework in which the welfare weight of the adult male vis-à-vis the adult female income earner, namely the 'bargaining power' variable, is jointly determined with the household's expenditure outcomes. In this paper, we follow this approach and adopt the empirical framework developed by Lancaster et al. (2006, 2008). We consider a household with two members, a man $(m)$ and a woman $(f)$. Utility depends on consumption $(x)$ and leisure (D). Following the collective approach developed by Browning and Chiappori (1998), the household's objective function can be written as the weighted sum of utilities of the two members. The household thus faces a utility maximization problem as follows:

$$
\operatorname{Max} \theta U_{f}\left(x_{m}, x_{f}, l_{m}, l_{f}\right)+(1-\theta) U_{m}\left(x_{m}, x_{f}, l_{m}, l_{f}\right),
$$

which is subject to the income constraint

$$
\sum_{i=m, f} p^{\prime} x_{i} \leq \sum_{i=m, f} w_{i}\left(T_{i}-l_{i}\right)+I .
$$

$U_{i}$ denotes the utility of member $i(i=m, f), x_{i}$ represents a vector of private consumption of individual $i ; w_{i}, T_{i}$, and $l_{i}$ correspond to the wage rate, time endowment and leisure of individual $i$. 
$I$ is the total unearned income of the household whereas $p$ represents a vector of prices for good $x$. In this setting, price, and wage are assumed to be exogenous. The welfare weight of member $f$, $\theta \in[0,1]$, depends on prices, household income, and other characteristics such as the distribution of income and bargaining power.

Equations (1) and (2) can be solved to obtain demand functions for each good $g{ }^{6}$ The household level budget shares of good $g$, $\left(b^{\circ}\right)$, can be written as the $\theta$-weighted average of the budget shares of that good for each spouse $(m, f)$, namely, $b_{f}^{g}$ and $b_{m}^{g}$, so that

$$
b^{g}=\theta b_{f}^{g}+(1-\theta) b_{m}^{g}
$$

The demand functions of education $(e d u)$ for each spouse $(m, f)$ is written as:

$$
\begin{aligned}
& b_{f}^{e d u}=\alpha_{f}^{e d u}+\beta_{f}^{e d u}[\theta \mu]+\epsilon_{f}^{e d u}, \\
& b_{m}^{e d u}=\alpha_{m}^{e d u}+\beta_{m}^{e d u}[(1-\theta) \mu]+\epsilon_{m}^{e d u},
\end{aligned}
$$

where $\theta$ is used as the income sharing rule and $\mu$ denotes the household income, so that $\theta \mu$ is the income assigned to the female and $(1-\theta) \mu$ is that assigned to the male. With regular datasets, one cannot use information on 'exclusive' goods, particularly spending by each household member, as such information is rarely collected in household surveys. With the inclusion of demographic variables (household size and age-sex composition) as independent variables, an aggregated budget share of education can be derived from Equations (3), (4), and (5) as follows:

$$
b=\alpha_{0}+\alpha_{1} \theta+\beta_{f} \theta^{2} \mu+\beta_{m}(1-\theta)^{2} \mu+\gamma \log (n)+\sum_{k=1}^{K} \varphi_{k}\left(\frac{n_{k}}{n}\right)+\varepsilon,
$$

where $n$ denotes the household size and $n_{k}$ the number of individuals in the age-sex group $k$.

With the data on hand (as described in Section 3), we can identify the amounts of expenditures on girls' and boys' education, hence allowing the calculation of gender-specific budget shares in the total household expenditures. In one version of the models, we can separately estimate for girls $(g)$ and boys $(b)$ :

$$
b^{g}=\alpha_{0}^{g}+\alpha_{1}^{g} \theta+\beta_{f}^{g} \theta^{2} \mu+\beta_{m}^{g}(1-\theta)^{2} \mu+\gamma \log (n)+\sum_{k=1}^{K} \varphi_{k}^{g}\left(\frac{n_{k}}{n}\right)+\varepsilon^{g}(7)
$$

and

$$
b^{b}=\alpha_{0}^{b}+\alpha_{1}^{b} \theta+\beta_{f}^{b} \theta^{2} \mu+\beta_{m}^{b}(1-\theta)^{2} \mu+\gamma \log (n)+\sum_{k=1}^{K} \varphi_{k}^{b}\left(\frac{n_{k}}{n}\right)+\varepsilon^{b}
$$

Hence, as in Lancaster et al. (2006), the bargaining power variable is jointly determined with the household's expenditure outcomes. We define a bargaining power, $\theta$, such as $\theta=\theta($ ₹), with z being a set of choice variables. These $z$ variables are then not exogenous, as in the traditional literature, but are part of the household's decision-making process. Indeed, the bargaining power could be deemed endogenous if it is correlated with the unobserved determinants of budget shares. $\theta$ is proxied by the share of the sum of gross wages earned by women in the household's

\footnotetext{
${ }^{6}$ See Lancaster et al. (2003) for details on the derivation procedure.

${ }^{7}$ The superscript $e d u$ is removed for simplicity.
} 
total gross wages, as a measure of female bargaining power within the household. Previous literature indicates that the extent to which a woman contributes to household income determines her say in decisions that affect the household (e.g. Blumberg and Coleman 1989; Desai and Jain 1994). Further, we also illustrate in Section 4.1 that female wage income share is significantly higher where female members have more decision-making power across several domains in the household.

We jointly estimate bargaining power, per capita household expenditure, and the budget share of education spending using the 3SLS estimation methodology. The advantage of this methodology is that it not only takes into account the potential endogeneity of bargaining power, expenditure, and budget share variables but also allows for mutual feedback between the equations via a nondiagonal covariance matrix of their residuals.

The following system of equations is thus estimated:

$$
\begin{aligned}
& \theta=\theta\left(X_{1}, T o t \operatorname{Exp}\right)+\vartheta_{1}, \\
& P C \operatorname{Exp}=P C \operatorname{Exp}\left(X_{2}\right)+\vartheta_{2}, \\
& b^{e d u}=b^{e d u}\left(\theta, P C E x p, X_{3}\right)+\vartheta_{3},
\end{aligned}
$$

where TotExp and PCExp represent, respectively, total household expenditure and per capita household expenditure; $X_{1}, X_{2}$, and $X_{3}$ are vectors of exogenous determinants; and $\vartheta_{1}, \vartheta_{2}$, and $\vartheta_{3}$ are stochastic error terms. $X_{1}$, in the bargaining power Equation (9a), includes the education share of adult females in household; its squared value, the log household size; dummies for caste, religion, and urban location; and age of the household head. $X_{2}$, in the log per capita expenditure Equation (9b), includes age; years of education; a sex dummy of the household head; dummies for caste, religion, and urban location; the total number of adults in household; and two household wealth controls (electricity, homeowner). $X_{3}$, the set of exogenous variables in the budget share of educational expenditure Equation (9c), includes the log household size, urban location, and share of individuals in different sex-age categories. The shares of male and female household members are classified into the following age groups: $0-4,5-9,10-14,15-19,20-55$, and over 55 years. Females over 55 years of age form the omitted category. In all regressions, we also include district dummy variables.

To explore how female bargaining power affects gender-specific educational expenditures, in one version of the 3SLS regressions, we replace the aggregated share of educational expenditures $b^{\text {edu }}$ by the shares of sex-specific educational expenditures, thus for boys $\left(b^{e d u_{b}}\right)$ and girls $\left(b^{e d u_{g}}\right)$. In all sets of estimates, we run separate regressions for rural and urban households.

\section{Data}

The data used in this paper are from the India Human Development Survey 2011-12 (IHDS-II) conducted by the University of Maryland in collaboration with the National Council of Applied Economic Research, New Delhi, between November 2011 and October 2012 (see Desai et al. 2011-12). The nationally representative data covers 1420 villages and 1042 urban areas across 33 states and union territories of India. ${ }^{8}$ The survey covering 42,152 households was carried out through face-to-face interviews conducted by pairs of male and female enumerators in local

\footnotetext{
${ }^{8}$ Andaman and Nicobar and Lakshadweep were not included in the sample.
} 
languages. The respondents included a person who was knowledgeable about the household economic situation (usually the male head of the household) and an ever-married woman aged 15-49 years. The detailed modules of the survey canvass data on a wide range of questions relating to economic activity, income and consumption expenditure, asset ownership, social capital, education, health, marriage, gender relationships, and fertility. ${ }^{9}$

As our primary interest is in understanding the allocation of educational expenditure, we restrict the analysis to households in which at least one member is aged 5-19 years. The educational expenditure data are collected at the household level and also individually for each child. Data are available for the following categories of education-related expenses for each enrolled child: school fees; schoolbooks, uniforms, and other materials; transportation; and private tuition. We calculate the total education expenditure as the sum of these categories.

\section{$4 \quad$ Results}

\subsection{Summary statistics}

Summary statistics are reported for the full sample and for rural and urban samples in Table 1. The share of female wages in total household wage income, our proxy of female bargaining power, is about 21 per cent. We find that wage income share of female members in the household is significantly lower in urban areas than in rural areas (16 versus 24 per cent). The share of adult female education in total adult education in the household is greater in urban areas than in rural areas. This reflects the higher educational attainment among women in urban areas but their lower labour force participation (and, consequently, lower wage contributions) as compared to rural women. ${ }^{10}$

In Table 2, we report additional statistics that help to check whether the share of female wages in total household wage income is able to reflect the extent to which women have a say in the decision-making process regarding household matters. We do this using the additional survey module administered to 'eligible women'. ${ }^{11}$ As this information is elicited from only a sub-sample of female members within households, we do not rely on these questions for our main estimation models to avoid reducing the sample sizes and representativeness of our findings. We first compute a score using answers by eligible women to questions regarding decision-making within the household across eight different domains including daily cooking, number of children to have, purchases of expensive items, buying and selling of land, expenditures on large social

\footnotetext{
${ }^{9}$ The India Human Development Survey 2011-12 (IHDS-II) data are a successor to the IHDS-I data. IHDS-I conducted in 2004-05 surveyed 41,554 households. IHDS-II re-interviewed about 83 per cent of these households, and used an additional replacement sample of 2134 households.

${ }^{10}$ Klasen and Pieters (2015) discuss the phenomenon of stagnating female labour force participation in urban India in the face of rising growth and female education, using five waves of India's National Sample Surveys. They find that supply and demand explanations can be advanced. On the supply side, rising male incomes and education as well as the reduction in selectivity of highly educated women have reduced female labour force participation. On the demand side, they find that growth in female-dominated sectors has been slow.

11 The eligible women in IHDS-II are all women interviewed in the previous 2005 wave, and an ever-married woman aged 15-49 years. The module covers health, education, fertility, family planning, marriage, and gender relationships in the household and community. Eligible women for whom we have information on qualitative measures of female bargaining power represent 40 per cent of the overall individual female sample we use, and live in households that represent 32 per cent of the overall household regression sample.
} 
functions, and child health. ${ }^{12}$ The final score of 'most say in decision-making' (the first variable), from 0 to 8 , is then clubbed into two categories (0-4 and 5-8) representing low and high values of this variable. Further, two dummy variables are constructed from questions with 'yes'/'no' answers: 'Do you yourself have any cash in hand to spend on household expenditures?' and 'Is your name there on any bank account?'. In Table 2, we report the mean values of the share of female wages in total household wage income across these three variables.

The share of female wages in total household wage income is always greater in households where female members have greater say in decision-making. In households where women have most say in five to eight decisions under consideration, the average female wage share is 0.45 as compared to 0.39 in households where women have a say in four or fewer decisions (two-sided $t$-test $P$ value $=0.00)$. A similar pattern exists for rural areas (two-sided $t$-test $P$ value $=0.00)$. In urban areas, although the female wage share is greater in households with more decision-making power for women, the difference fails to be significant at conventional levels. Further, households where at least one female has cash to spend on household expenditures and those with female members having their name on a bank account display a significantly higher mean value of female bargaining power proxy than households without such women, in rural and urban areas alike. Two-sided $t$-tests are significant at the 1 per cent level in all these cases. Altogether, these results comfort us that the financial measure of bargaining power use in this study is consistent with other decision-making-based measures of female autonomy in the data. ${ }^{13}$

We now turn to discussing other descriptive statistics in Table 1. On average, the share of household expenditure devoted to education is about 5.5 per cent, with the corresponding averages in rural and urban areas being 4.5 and 7.8 per cent, respectively. In both rural and urban areas, we find that the share of household budget on girls' education is lower than that incurred on boys' education. In Table 3, we present the average educational expenditures for boys and girls by age and location. The key points to note are: first, education expenditures are increasing in age for both boys and girls in all areas; second, significantly more is spent on boys than on girls and this gender gap in expenditures tends to be higher in older age groups; third, the gender gap in expenditures is generally smaller in rural than in urban areas for all age groups. Further, in statistics not reported here, we find that, for each category of educational expenditure-school fees, schoolbooks, uniforms and other materials, transportation, and private tuition-families spend significantly lower amounts on girls than on boys. ${ }^{14}$

As expected, households in urban areas tend to be better off, as is evident from higher total household consumption expenditures and also higher per capita expenditures in urban areas. In urban areas, heads of households, on average, also have greater educational attainment than their

${ }^{12}$ For each particular domain, where the eligible woman has the most say, she gets a score equal to 1 , and 0 otherwise. We add these scores to obtain a total score for the household and then divide it by the number of eligible women respondents in each household to arrive at a score ranging from 0 to 8 .

${ }^{13}$ We tried alternative ways of computing female bargaining power proxy. A first possibility would be to use the female wage share of the most significant income-earning couple. This is difficult to identify in non-nuclear households and/or when the household head is not an income earner. A second possibility is to identify the ratio of wage incomes of actual parents of children of school-going age in the households. In cases with no identifiable parents of these children it was difficult to identify caregivers. Another option was to use current asset ownership by women, inherited assets, or assets brought to the marriage by women, all proxies of female bargaining power that have been used in previous literature. However, the survey does not contain such information.

14 Azam (2015), using three rounds of 'Participation and Expenditure in Education' Survey data, documents the incidence and cost of private tutoring at different stages of schooling in India. Using a hurdle model, he finds a promale bias in enrolment and expenditure decisions regarding private tuitions. 
counterparts in rural areas. The average age of the household head, average household size, and the proportion of male-headed households are similar across rural and urban areas. We observe greater proportions of SCSTs and lower proportions of upper castes in rural areas in our data, whereas the share of OBCs is fairly similar across areas.

\subsection{Estimation results}

We first discuss 3SLS estimates of the system of Equations (9a), (9b), and (9c). Given the existence of differences in educational expenditures, female share of wage income and other characteristics between rural and urban areas (as shown in Section 4.1), we report all the regressions disaggregated by location. It should be noted that for each of the regressions that follow, the Breusch-Pagan test statistic shows a clear rejection of the null hypothesis of diagonal covariance matrix of the disturbance terms, thereby justifying the use of the 3SLS technique instead of ordinary least squares (OLS). As a robustness check, we also report OLS regressions for comparison in Appendix Tables A1 and A2 for the pooled, rural, and urban samples. ${ }^{15}$

\section{Determinants of balance of power}

Table 4 presents the coefficient estimates of the female bargaining power Equation ( $9 \mathrm{a}$ ) for the full sample and for rural and urban samples separately. The female bargaining power is negatively associated with the household size, implying that this power is weaker in larger households. The magnitude of the household size coefficient is larger for urban households. Similarly, ceteris paribus, the negative sign on the urban dummy reveals that female members in urban households have lower bargaining power, as also seen in the descriptive statistics in Table 1. As the female share of total educational attainment in the household increases, female bargaining power initially decreases, but less and less, till it reaches a minimum to then rise again. The returns to the household share of female education on female bargaining power hence describe a U-curve: at the average points of the samples, these returns for the overall, rural, and urban samples are 0.17, 0.13 , and 0.24 , respectively. Female education is thus more powerful for improving female bargaining power in urban areas.

Other coefficients are worth commenting on. The coefficients on total household expenditure are positive and significant in the pooled sample, but disaggregated results show that this is driven by only urban households. Interestingly, age of the household head is positively associated with greater female bargaining power. Urban Hindu households report greater bargaining power for female members compared to households belonging to other religions. Low caste households (SCSTs and OBCs) in rural areas exhibit a greater female bargaining power compared to upper caste households. This result is in accordance with the assumption that low caste women experience greater autonomy and control over household resources, and that attitudes towards women may be more liberal in general compared to upper caste women who face greater restrictions on mobility, decision-making, and labour force participation owing to the value placed on ritual purity.

Table 5 presents the coefficient estimates of the same specification using segmented samples by caste for urban and rural areas. The regressions again indicate that female bargaining power is negatively associated with household size. The returns to share of female education on female bargaining power proxy confirm the U-curve pattern, except for upper caste households in rural areas, for whom the effect is rather linearly increasing. Irrespective of location of households, female members in upper caste households get higher returns for their education in terms of

\footnotetext{
${ }^{15}$ The detailed OLS results are available upon request from the authors.
} 
bargaining power: the returns at sample means are $0.19,0.10,0.15$, respectively, for upper caste, SCST, and OBC groups in rural areas, whereas these returns are $0.40,0.20$, and 0.18 , respectively, for households in urban localities. For upper caste households in urban areas, this suggests that a 1 per cent increase in female education share within the household leads to a 4 per cent increase in the female wage share.

\section{Determinants of per capita household expenditure}

Table 6 presents the 3SLS coefficient estimates of the determinants of log per capita expenditure as shown in Equation (9b) for the full sample, and for rural and urban samples. These mostly conform to intuition and are in accordance with previous literature: SCSTs and OBCs are worseoff than upper castes, Hindu households fare better than those of other religions, and households in urban areas are richer than those in rural ones. More educated and older household heads are associated with richer households. One surprising result is the negative association between the household head being male and the log per capita expenditure. This is contrary to previous literature that typically finds households headed by female members to be poorer and more vulnerable. We also obtain the same result using OLS regressions reported in Appendix Table A2.

\section{Determinants of budget share of educational expenditures}

In Table 7, we report the 3SLS estimates of the budget share of educational expenditures as shown in Equation (9c) for the full sample, and for rural and urban samples. In terms of assessing the effects of female bargaining power on the expenditure share of education, note that there are two channels through which it works. The first is the direct effect as measured by the coefficient of $\theta$, and the second is through the income-sharing rule. Only considering one or the other would not take into account the full picture. Using Equation (6), we test jointly whether $\alpha_{1}=0$ and $\beta_{m} \theta=\beta_{f}(1-\theta)$. As this test will be dependent on the value of $\theta$, we report the Wald test statistics at the bottom of Table 7 and all the other tables as well, for the following values of $\theta .0,0.2,0.4,0.6,0.8$, and 1 . The null hypothesis is that the bargaining power has no effect, which would conform to the unitary household model against the collective model. We also report the joint effects of female bargaining power in the bottom panel of the table, which are evaluated at the average values of per capita expenditure and $\theta$. As the $t$-statistics indicate, in column (1) for the full sample, female bargaining power is positively associated with the share of household budget devoted to education. This is in accordance with previous literature from India and other developing countries that greater female bargaining power leads to better outcomes for children. However, we note that there are differential effects in rural and urban areas such that the effect of female bargaining power is negative in rural areas and positive in urban areas.

In terms of other covariates, as seen previously in Table 1, we find the share of household spending on education to be significantly higher in urban areas and in larger households. At any given level of household expenditure, larger households are bound to be better off because of the economies of scale on account of shared goods within the household.

In Table 8, we estimate Equation (9c) separately for each of the three caste groups in rural and urban areas. In columns (1)-(3), testing the joint effect of female bargaining power at average values of household expenditure and $\theta$ indicates that the female wage share is not a significant predictor of educational spending among rural upper caste and rural SCST households but it negatively affects budget share of education only among rural OBCs. This implies that the result documented in column (2) of Table 7 is being largely driven by the findings emerging from the 
OBC sample in rural areas. On the other hand, in urban areas, as seen in columns (4)-(6), at average values of $\theta$ for all caste groups, we observe a positive and significant relationship between our proxy of female power and educational spending, with effects being larger among upper castes and SCSTs as compared to OBCs.

We test for systematic differences in the effects of the age-sex composition variables (i.e. agesex shares in household size) in the budget share equations. A significant negative difference between female and male members within an age group would indicate the existence of a significant pro-male bias in educational expenditures for that specific age group. In Table 9, we list the difference in marginal effects (defined as female minus male) for age groups 5-9, 10-14, and 15-19 years for rural and urban areas and for each caste group. Note that these are derived from regression results reported in Tables 7 and 8 . For the full sample, the difference in the marginal effects (female minus male) is negative and statistically significant for all the age groups, implying that families spend more on boys' education than that of girls (column (1)). As columns (2) and (3) indicate, we observe differences based on location. In rural areas, the difference in marginal effects is significant for the age group 10-14 years, reflecting that, in these areas, this is a decisive age group as parents may make girls help out with household chores leading to dropouts or lower school attendance. In urban areas, the gender gap is significant only for the age group 5-9 years, indicating a large gap of more than 4 percentage points to the detriment of girls.

Moving onto differences by caste, in rural areas, the gender gap in educational expenditure is significant for the following age groups: 5-9 years (among OBCs), 10-14 years (among SCSTs and OBCs), and 15-19 years (among upper castes and SCSTs). In urban areas, this gender gap in educational spending is significant for the following age groups: 5-9 years (among upper castes and OBCs), 10-14 years (among SCSTs), and 15-19 years (among upper castes). We observe that for each of the caste groups, gaps seem larger in urban than in rural areas. Further, in urban areas, although the gender gap is always significant for upper castes (with the exception of the age group 10-14 years, where the difference is significant at a 12 per cent level of significance), it is significant in fewer cases for SCSTs and OBCs.

\section{Determinants of budget share of sex-specific educational expenditures}

In Table 10, we estimate the system of equations separately for boys and girls, where Equation (9c) measures the share of household expenditures on girls' education and on boys' education, respectively. Looking at columns (1) and (2), we see that female bargaining power appears to matter uniformly for educational expenditure on girls but not always for that on boys. Further, at average values, it has a positive and significant effect on share on girls' educational expenditure but the effect is not significant for spending on boys' education. This is in accordance with some previous findings in the literature indicating that the mother's influence within the household has a more positive impact on girls' outcomes (e.g. Duflo 2003; Qian 2008; Thomas 1990). In columns (3) and (4), in rural areas, we find female bargaining power to have a negative and significant effect on household education budget devoted to girls but an insignificant (although negative) effect on boys' education. By contrast, in urban areas, girls' educational expenditure is positively affected by the bargaining power of female members in the household, whereas the average effect is negative for boys.

We also estimate the same regressions by caste groups in rural and urban areas. Results for rural areas, reported in Table 11, reveal mostly insignificant and small effects of female bargaining power and educational spending on boys and girls. The only exception is rural OBC households where female bargaining power translates into lower spending on education for girls. Conversely, as Table 12 shows, in urban areas, across all three caste groups, the evidence uniformly indicates 
that an improvement in female bargaining power within the household leads to significantly greater educational outlays for girls. Further, it should be noted that the average effect of female bargaining power is greater with respect to girls' educational expenditure than that for boys for all caste groups. Among OBCs, examining sex-specific expenditures shows a negative effect on expenditures allocated to boys' education.

\section{Conclusion}

In this paper, our objective has been to assess the impact of female bargaining power-as measured by the wage income share of female members in the household-on the share of educational expenditures in household budget. We augment the collective household model by endogenizing female bargaining power and use a 3SLS approach to simultaneously estimate female bargaining power, per capita household expenditure, and budget share of education.

In line with the literature that shows maternal autonomy to positively determine child outcomes, we find that female bargaining power increases the share of household budget devoted to children's education. However, this relationship varies by location such that a positive association is observed in urban areas whereas the correlation is negative in rural areas. Segmenting the sample by a household's caste affiliation and exploiting the availability of individual-level educational expenditure data, in urban areas, across all three broad caste groups, evidence uniformly indicates that an improvement in female bargaining power within the household leads to significantly greater educational outlays for girls. These results find support from previous literature indicating that female bargaining power reaps greater returns for girls than for boys. Our results also suggest that the gender bias in favour of boys differs along caste lines, especially in urban areas where the pro-male bias is almost always significant among upper castes but is significant in fewer cases among SCSTs and OBCs. 


\section{References}

Afridi, F. (2010). 'Women's Empowerment and the Goal of Parity Between the Sexes in Schooling in India'. Population Studies, 64(2): 131-45.

Alfano, M., W. Arulampalam, and U. Kambhampati (2011). 'Maternal Autonomy and the Education of the Subsequent Generation: Evidence from Three Contrasting States in India'. IZA Discussion Paper 6019. Bonn: Institute for the Study of Labour. Available at: http:/ / ftp.iza.org/dp6019.pdf (accessed 20 April 2016).

Azam, M. (2015). 'Private Tutoring: Evidence from India'. IZA Discussion Paper 8770. Bonn: Institute for the Study of Labour. Available at: http://ftp.iza.org/dp8770.pdf (accessed 20 April 2016). [Forthcoming in Review of Development Economics.]

Azam, M., and G. Kingdon (2013). 'Are Girls the Fairer Sex in India? Revisiting IntraHousehold Allocation of Education Expenditure'. World Development, 42: 143-64.

Basu, K. (2006). 'Gender and Say: A Model of Household Behavior with Endogenously Determined Balance of Power'. The Economic Journal, 116(511): 558-80.

Blumberg, R., and M. Coleman (1989). 'A Theoretical Look at the Gender Balance of Power in the American Couple'. Journal of Family Issues, 10(2): 225-50.

Bourguignon, F., M. Browning, P.A. Chiappori, and V. Lechene (1993). 'Intrahousehold Allocation of Consumption: Some Evidence on French Data'. Annales d'Economie et de Statistique, 29: 137-56.

Browning. M., and P.A. Chiappori (1998). 'Efficient Intra Household Allocations: A General Characterisation and Empirical Tests'. Econometrica, 66(6): 1241-78.

Chakravarti, U. (1993). 'Conceptualizing Brahmanical Patriarchy in Early India: Gender, Caste, Class and State'. Economic and Political Weekly, 28(14): 579-85.

Dasgupta, U., and S. Mani (2015). 'Only Mine or All Ours: Do Stronger Entitlements Affect Altruistic Choices in the Household'. World Development, 67: 363-75.

Desai, S., and D. Jain (1994). 'Maternal Employment and Family Dynamics: The Social Context of Women's Work in Rural South India'. Population and Development Review, 20(1): 115-36.

Desai, S., R. Vaaneman, and National Council of Applied Economic Research (2011-12). India Human Development Survey II (IHDS-II). Ann Arbor, MI: Inter-University Consortium for Political and Social Research. Available at: http://ihds.info/IHDS-II (accessed 19 April 2016).

Doss, C. (2013). 'Intrahousehold Bargaining and Resource Allocation in Developing Countries'. World Bank Research Observer, 28(1): 52-78.

Duflo, E. (2003). 'Grandmothers and Granddaughters: Old-Age Pensions and Intrahousehold Allocation in South Africa'. World Bank Economic Review, 17(1): 1-25.

Duflo, E. (2012). 'Women Empowerment and Economic Development'. Journal of Economic Literature, 50(4): 1051-79.

Eswaran, M., B. Ramaswami, and W. Wadhwa (2013). 'Status, Caste, and the Time Allocation of Women in Rural India'. Economic Development and Cultural Change, 61(2): 311-33.

Jayachandran, S. (2015). 'The Roots of Gender Inequality in Developing Countries'. Annual Review of Economics, 7(1): 63-88.

Kapadia, K. (1997). 'Mediating the Meaning of Market Opportunities: Gender, Caste and Class in Rural South India'. Economic and Political Weekly, 35(52): 3329-35. 
Kingdon, G.G. (2005). 'Where Has All the Bias Gone? Detecting Gender Bias in the Intrahousehold Allocation of Educational Expenditure'. Economic Development and Cultural Change, 53(2): 409-52.

Klasen, S., and J. Pieters (2015). 'What Explains the Stagnation of Female Labor Force Participation in Urban India?'. World Bank Economic Review, 29(3): 449-78.

Lancaster. G., P. Maitra, and R. Ray (2003). 'Endogenous Power, Household Expenditure Patterns and New Tests of Gender Bias: Evidence from India'. Working paper. Available at: https://editorialexpress.com/cgi-

bin/conference/download.coi?db_name=esam2003\&amp;paper_id=168 (accessed 28 April 2016).

Lancaster. G., P. Maitra, and R. Ray (2006). 'Endogenous Intra-household Balance of Power and Its Impact on Expenditure: Evidence from India'. Economica, 73(291): 435-60.

Lancaster. G., P. Maitra, and R. Ray (2008). 'Household Expenditure Patterns and Gender Bias: Evidence from Selected Indian States'. Oxford Development Studies, 36(2): 133-57.

Mencher, J.P. (1988). 'Women's Work and Poverty: Women's Contribution to Household Maintenance in South India'. In D. Dwyer and J. Bruce (eds), A Home Divided: Women and Income in the Third World. Stanford, CA: Stanford University Press, pp. 99-119.

Menon, N., Y. Rodgers, and H. Nguyen (2014). 'Women's Land Rights and Children's Human Capital in Vietnam'. World Development, 54: 18-31.

Mitra, A. (2008). 'The Status of Women Among the Scheduled Tribes in India'. The Journal of Socio-Economics, 37(3): 1202-17.

Qian, N. (2008). 'Missing Women and the Price of Tea in China: the Effect of Income on Sex Imbalance'. Quarterly Journal of Economics, 123(3): 1251-85.

Quisumbing, A., and J. Maluccio (2003). 'Resources at Marriage and Intra-household Allocation: Evidence from Bangladesh, Ethiopia, Indonesia and South Africa'. Oxford Bulletin of Economics and Statistics, 65(3): 283-327.

Rangel, M. (2006). 'Alimony Rights and Intrahousehold Allocation of Resources: Evidence from Brazil'. The Economic Joumal, 116(513): 627-58.

Reggio, I. (2011). 'The Influence of the Mother's Power on Her Child's Labor in Mexico. Journal of Development Economics, 96(1): 95-105.

Subramanian, S., and A. Deaton (1991). 'Gender Effects in Indian Consumption Patterns'. Sarvekshana, 14(4): 1-12.

Thomas, D. (1990). 'Intra-household Resource Allocation: An Inferential Approach'. Journal of Human Resources, 25(4): 635-64.

World Bank (2012). World Development Report: Gender, Equality and Development. World Bank: Washington, DC.

Zimmerman, L. (2012). 'Reconsidering Gender Bias in Intrahousehold Allocation in India'. Journal of Development Studies, 48(1): 151-63. 
Table 1: Summary statistics

\begin{tabular}{|c|c|c|c|}
\hline Variables & All & Rural & Urban \\
\hline Female wage income share & $\begin{array}{l}0.21 \\
(0.314)\end{array}$ & $\begin{array}{l}0.235 \\
(0.318)\end{array}$ & $\begin{array}{l}0.158 \\
(0.299)\end{array}$ \\
\hline Share of female education & $\begin{array}{l}0.386 \\
(0.292)\end{array}$ & $\begin{array}{l}0.364 \\
(0.31)\end{array}$ & $\begin{array}{l}0.426 \\
(0.252)\end{array}$ \\
\hline Budget share of education & $\begin{array}{l}0.055 \\
(0.077)\end{array}$ & $\begin{array}{l}0.045 \\
(0.067)\end{array}$ & $\begin{array}{l}0.078 \\
(0.091)\end{array}$ \\
\hline Budget share of education on boys & $\begin{array}{l}0.043 \\
(0.063)\end{array}$ & $\begin{array}{l}0.034 \\
(0.055)\end{array}$ & $\begin{array}{l}0.06 \\
(0.075)\end{array}$ \\
\hline Budget share of education on girls & $\begin{array}{l}0.035 \\
(0.057)\end{array}$ & $\begin{array}{l}0.027 \\
(0.048)\end{array}$ & $\begin{array}{l}0.052 \\
(0.072)\end{array}$ \\
\hline Household size & $\begin{array}{l}5.566 \\
(2.173)\end{array}$ & $\begin{array}{l}5.623 \\
(2.184)\end{array}$ & $\begin{array}{l}5.449 \\
(2.145)\end{array}$ \\
\hline Adults & $\begin{array}{l}2.912 \\
(1.39)\end{array}$ & $\begin{array}{l}2.861 \\
(1.362)\end{array}$ & $\begin{array}{l}3.019 \\
(1.44)\end{array}$ \\
\hline Total household expenditure (INR) & $\begin{array}{l}111,833.3 \\
(99,582.73)\end{array}$ & $\begin{array}{l}96,655.43 \\
(92,018.19)\end{array}$ & $\begin{array}{l}143,303.9 \\
(107,029.8)\end{array}$ \\
\hline Per capita expenditure (INR) & $\begin{array}{l}21,470.56 \\
(20,313.76)\end{array}$ & $\begin{array}{l}18,156.24 \\
(18,331.33)\end{array}$ & $\begin{array}{l}28,342.69 \\
(22,395.54)\end{array}$ \\
\hline Male household head & $\begin{array}{l}0.891 \\
(0.312)\end{array}$ & $\begin{array}{l}0.894 \\
(0.308)\end{array}$ & $\begin{array}{l}0.885 \\
(0.319)\end{array}$ \\
\hline Household head age (years) & $\begin{array}{l}46.874 \\
(12.045)\end{array}$ & $\begin{array}{l}46.710 \\
(12.339)\end{array}$ & $\begin{array}{l}47.214 \\
(11.404)\end{array}$ \\
\hline $\begin{array}{l}\text { Years of education of household } \\
\text { head }\end{array}$ & $\begin{array}{l}5.206 \\
(4.806)\end{array}$ & $\begin{array}{l}4.254 \\
(4.436)\end{array}$ & $\begin{array}{l}7.180 \\
(4.944)\end{array}$ \\
\hline Urban & $\begin{array}{l}0.325 \\
(0.468)\end{array}$ & & \\
\hline Hindu & $\begin{array}{l}0.811 \\
(0.392)\end{array}$ & $\begin{array}{l}0.829 \\
(0.377)\end{array}$ & $\begin{array}{l}0.773 \\
(0.419)\end{array}$ \\
\hline Scheduled caste/tribe & $\begin{array}{l}0.368 \\
(0.482)\end{array}$ & $\begin{array}{l}0.415 \\
(0.493)\end{array}$ & $\begin{array}{l}0.268 \\
(0.443)\end{array}$ \\
\hline Other backward classes & $\begin{array}{l}0.396 \\
(0.489)\end{array}$ & $\begin{array}{l}0.389 \\
(0.487)\end{array}$ & $\begin{array}{l}0.410 \\
(0.492)\end{array}$ \\
\hline Upper castes & $\begin{array}{l}0.226 \\
(0.418)\end{array}$ & $\begin{array}{l}0.186 \\
(0.389)\end{array}$ & $\begin{array}{l}0.308 \\
(0.462)\end{array}$ \\
\hline Share: males aged 0-4 years & $\begin{array}{l}0.031 \\
(0.073)\end{array}$ & $\begin{array}{l}0.034 \\
(0.076)\end{array}$ & $\begin{array}{l}0.025 \\
(0.065)\end{array}$ \\
\hline Share: females aged $0-4$ years & $\begin{array}{l}0.029 \\
(0.072)\end{array}$ & $\begin{array}{l}0.032 \\
(0.076)\end{array}$ & $\begin{array}{l}0.024 \\
(0.065)\end{array}$ \\
\hline Share: males aged $5-9$ years & $\begin{array}{l}0.063 \\
(0.106)\end{array}$ & $\begin{array}{l}0.066 \\
(0.108)\end{array}$ & $\begin{array}{l}0.057 \\
(0.102)\end{array}$ \\
\hline Share: females aged $5-9$ years & $\begin{array}{l}0.055 \\
(0.10)\end{array}$ & $\begin{array}{l}0.059 \\
(0.102)\end{array}$ & $\begin{array}{l}0.048 \\
(0.095)\end{array}$ \\
\hline Share: males aged $10-14$ years & $\begin{array}{l}0.074 \\
(0.118)\end{array}$ & $\begin{array}{l}0.076 \\
(0.119)\end{array}$ & $\begin{array}{l}0.069 \\
(0.115)\end{array}$ \\
\hline Share: females aged $10-14$ years & $\begin{array}{l}0.066 \\
(0.11)\end{array}$ & $\begin{array}{l}0.067 \\
(0.111)\end{array}$ & $\begin{array}{l}0.062 \\
(0.109)\end{array}$ \\
\hline Share: males aged $15-19$ years & $\begin{array}{l}0.068 \\
(0.117)\end{array}$ & $\begin{array}{l}0.067 \\
(0.116)\end{array}$ & $\begin{array}{l}0.072 \\
(0.119)\end{array}$ \\
\hline Share: females aged $15-19$ years & $\begin{array}{l}0.064 \\
(0.11)\end{array}$ & $\begin{array}{l}0.063 \\
(0.11)\end{array}$ & $\begin{array}{l}0.064 \\
(0.109)\end{array}$ \\
\hline Share: males aged $20-55$ years & $\begin{array}{l}0.229 \\
(0.114)\end{array}$ & $\begin{array}{l}0.221 \\
(0.114)\end{array}$ & $\begin{array}{l}0.247 \\
(0.114)\end{array}$ \\
\hline Share: females aged $20-55$ years & $\begin{array}{l}0.237 \\
(0.098)\end{array}$ & $\begin{array}{l}0.23 \\
(0.096)\end{array}$ & $\begin{array}{l}0.253 \\
(0.101)\end{array}$ \\
\hline Share: males aged over 55 years & $\begin{array}{l}0.037 \\
(0.076)\end{array}$ & $\begin{array}{l}0.039 \\
(0.078)\end{array}$ & $\begin{array}{l}0.033 \\
(0.073)\end{array}$ \\
\hline Share: females aged over 55 years & $\begin{array}{l}0.044 \\
(0.082)\end{array}$ & $\begin{array}{l}0.045 \\
(0.083)\end{array}$ & $\begin{array}{l}0.044 \\
(0.081)\end{array}$ \\
\hline Observations & 20,631 & 13,919 & 6,712 \\
\hline
\end{tabular}

Note: INR, Indian rupees. Standard deviations in parentheses.

Source: Authors' calculations using India Human Development Survey 2011-12 (IHDS-II) data. 
Table 2: Mean variation of the share of female wages income in the household across qualitative measures of female autonomy

\begin{tabular}{|c|c|c|c|c|c|c|}
\hline & \multicolumn{2}{|c|}{ All } & \multicolumn{2}{|c|}{ Rural } & \multicolumn{2}{|c|}{ Urban } \\
\hline & $\begin{array}{l}\text { Share of } \\
\text { female wage } \\
\text { income (\%) }\end{array}$ & $\begin{array}{l}N \\
\text { (households) }\end{array}$ & $\begin{array}{l}\text { Share of } \\
\text { female wage } \\
\text { income }(\%)\end{array}$ & $\begin{array}{l}N \\
\text { (households) }\end{array}$ & $\begin{array}{l}\text { Share of } \\
\text { female wage } \\
\text { income (\%) }\end{array}$ & $\begin{array}{l} \\
\text { (households) }\end{array}$ \\
\hline \multicolumn{7}{|c|}{ Household index of 'most say in decision-making' } \\
\hline $0-4$ & 0.39 & 864 & 0.38 & 731 & 0.44 & 133 \\
\hline $5-8$ & 0.45 & $\begin{array}{l}8675 \\
9539\end{array}$ & 0.44 & $\begin{array}{l}6847 \\
7578\end{array}$ & 0.49 & $\begin{array}{l}1828 \\
1961\end{array}$ \\
\hline$t$-Test of mean difference & & 87 & & 39 & & 01 \\
\hline \multicolumn{7}{|c|}{ Household with females having cash to spend on household expenditures } \\
\hline No & 0.39 & 644 & 0.40 & 535 & 0.37 & 109 \\
\hline Yes & 0.45 & $\begin{array}{l}9977 \\
10,621\end{array}$ & 0.44 & $\begin{array}{l}7851 \\
8386\end{array}$ & 0.51 & $\begin{array}{l}2126 \\
2235\end{array}$ \\
\hline$t$-Test of mean difference & & 57 & & 86 & & 14 \\
\hline \multicolumn{7}{|c|}{ Household with females having their name on bank account } \\
\hline No & 0.39 & 2267 & 0.39 & 1,908 & 0.42 & 359 \\
\hline Yes & 0.49 & $\begin{array}{l}4833 \\
7100\end{array}$ & 0.47 & $\begin{array}{l}3641 \\
5549\end{array}$ & 0.55 & $\begin{array}{l}1192 \\
1551\end{array}$ \\
\hline$t$-Test of mean difference & & .82 & & 98 & & 85 \\
\hline
\end{tabular}

Source: Authors' calculations using IHDS-II data.

Table 3: Educational expenditure by age (years), location, and gender

\begin{tabular}{|c|c|c|c|c|c|c|c|c|c|}
\hline & \multicolumn{3}{|c|}{ All } & \multicolumn{3}{|c|}{ Rural } & \multicolumn{3}{|c|}{ Urban } \\
\hline & $5-9$ & $10-14$ & $15-19$ & $5-9$ & $10-14$ & $15-19$ & $5-9$ & $10-14$ & $15-19$ \\
\hline Boys & 3420.2 & 3972.9 & 6065.3 & 2257.4 & 2771.3 & 4451.3 & 6186.2 & 6602.8 & 9163.6 \\
\hline Girls & 2758.9 & 3090.6 & 4523.1 & 1759.7 & 1936.9 & 3025.9 & 5199.6 & 5696.9 & 7586.9 \\
\hline Difference & $661.3^{* * *}$ & $882.2^{* * *}$ & $1542.1^{* * *}$ & $497.72^{* * *}$ & $834.42^{* \star *}$ & $1425.4^{\star * *}$ & $986.6^{\star * *}$ & $905.9^{* * *}$ & $1576.6^{\star * *}$ \\
\hline
\end{tabular}

Note: ${ }^{* \star *}$ denotes significance at 1 per cent level. All values are in Indian rupees.

Source: Authors' calculations using IHDS-II data.

Table 4: Three-stage least squares (3SLS) estimates of female bargaining power

\begin{tabular}{|c|c|c|c|}
\hline & $\begin{array}{l}\text { (1) } \\
\text { All }\end{array}$ & $\begin{array}{l}(2) \\
\text { Rural } \\
\end{array}$ & $\begin{array}{l}\text { (3) } \\
\text { Urban }\end{array}$ \\
\hline Share of female education in total education & $\begin{array}{l}-0.195^{\star \star \star} \\
(0.021)\end{array}$ & $\begin{array}{l}-0.176^{\star \star \star} \\
(0.025)\end{array}$ & $\begin{array}{l}-0.289^{\star \star \star} \\
(0.039)\end{array}$ \\
\hline Share of female education squared & $\begin{array}{l}0.472^{* \star *} \\
(0.022)\end{array}$ & $\begin{array}{l}0.424^{\star \star \star} \\
(0.026)\end{array}$ & $\begin{array}{l}0.629^{* * *} \\
(0.041)\end{array}$ \\
\hline Log (total expenditure) & $\begin{array}{l}0.021^{* * *} \\
(0.004)\end{array}$ & $\begin{array}{l}0.001 \\
(0.006)\end{array}$ & $\begin{array}{l}0.043^{* \star *} \\
(0.007)\end{array}$ \\
\hline Log (household size) & $\begin{array}{l}-0.097^{\star * \star} \\
(0.007)\end{array}$ & $\begin{array}{l}-0.082^{\star \star \star} \\
(0.009)\end{array}$ & $\begin{array}{l}-0.108^{\star \star \star} \\
(0.011)\end{array}$ \\
\hline Hindu & $\begin{array}{l}0.024^{\star \star *} \\
(0.006)\end{array}$ & $\begin{array}{l}0.000 \\
(0.009)\end{array}$ & $\begin{array}{l}0.037^{* * *} \\
(0.010)\end{array}$ \\
\hline SCST & $\begin{array}{l}0.026^{* * *} \\
(0.006)\end{array}$ & $\begin{array}{l}0.050^{* * *} \\
(0.008)\end{array}$ & $\begin{array}{l}-0.008 \\
(0.010)\end{array}$ \\
\hline OBC & $\begin{array}{l}0.009 \\
(0.006)\end{array}$ & $\begin{array}{l}0.029^{* * *} \\
(0.008)\end{array}$ & $\begin{array}{l}-0.013 \\
(0.009)\end{array}$ \\
\hline Age of head & $\begin{array}{l}0.079^{\star \star *} \\
(0.009)\end{array}$ & $\begin{array}{l}0.070^{\star \star *} \\
(0.011)\end{array}$ & $\begin{array}{l}0.102^{* \star *} \\
(0.016)\end{array}$ \\
\hline Urban & $\begin{array}{l}-0.052^{\star \star *} \\
(0.007)\end{array}$ & & \\
\hline Constant & $\begin{array}{l}-0.334^{* * *} \\
(0.062)\end{array}$ & $\begin{array}{l}-0.113 \\
(0.078)\end{array}$ & $\begin{array}{l}-0.646^{* * *} \\
(0.105)\end{array}$ \\
\hline $\begin{array}{l}\text { Observations } \\
R^{2}\end{array}$ & $\begin{array}{l}17,603 \\
0.180 \\
\end{array}$ & $\begin{array}{l}11,323 \\
0.194 \\
\end{array}$ & $\begin{array}{l}6280 \\
0.179 \\
\end{array}$ \\
\hline
\end{tabular}

Note: Standard errors in parentheses. * ${ }^{* *}$, and ${ }^{* *}$ denote significance at 10,5 , and 1 per cent levels, respectively. District dummy variables are included.

Source: Authors' calculations using IHDS-II data. 
Table 5: 3SLS estimates of female bargaining power by castes

\begin{tabular}{|c|c|c|c|c|c|c|}
\hline & $(1)$ & (2) & (3) & $(4)$ & $(5)$ & (6) \\
\hline & \multicolumn{3}{|c|}{ Rural } & \multicolumn{3}{|c|}{ Urban } \\
\hline & Upper castes & SCSTS & OBCs & Upper castes & SCSTS & OBCs \\
\hline $\begin{array}{l}\text { Share of female education in total } \\
\text { education }\end{array}$ & $\begin{array}{l}-0.044 \\
(0.063)\end{array}$ & $\begin{array}{l}-0.172^{* * *} \\
(0.038)\end{array}$ & $\begin{array}{l}-0.165^{\star * \star} \\
(0.041)\end{array}$ & $\begin{array}{l}-0.276^{* * *} \\
(0.085)\end{array}$ & $\begin{array}{l}-0.189^{* * *} \\
(0.066)\end{array}$ & $\begin{array}{l}-0.301^{* * *} \\
(0.057)\end{array}$ \\
\hline Share of female education squared & $\begin{array}{l}0.279^{* * *} \\
(0.064)\end{array}$ & $\begin{array}{l}0.405^{\star * *} \\
(0.040)\end{array}$ & $\begin{array}{l}0.452^{* * *} \\
(0.043)\end{array}$ & $\begin{array}{l}0.744^{* \star *} \\
(0.088)\end{array}$ & $\begin{array}{l}0.476^{* * *} \\
(0.071)\end{array}$ & $\begin{array}{l}0.594^{\star \star *} \\
(0.062)\end{array}$ \\
\hline Log (total expenditure) & $\begin{array}{l}0.030^{* *} \\
(0.013)\end{array}$ & $\begin{array}{l}0.005 \\
(0.009)\end{array}$ & $\begin{array}{l}-0.008 \\
(0.009)\end{array}$ & $\begin{array}{l}0.072^{* * *} \\
(0.013)\end{array}$ & $\begin{array}{l}0.026^{*} \\
(0.013)\end{array}$ & $\begin{array}{l}0.036^{\star * *} \\
(0.011)\end{array}$ \\
\hline Log (household size) & $\begin{array}{l}-0.088^{* * *} \\
(0.020)\end{array}$ & $\begin{array}{l}-0.086^{* * *} \\
(0.014)\end{array}$ & $\begin{array}{l}-0.082^{* \star *} \\
(0.014)\end{array}$ & $\begin{array}{l}-0.079^{\star * \star} \\
(0.021)\end{array}$ & $\begin{array}{l}-0.116^{\star \star *} \\
(0.023)\end{array}$ & $\begin{array}{l}-0.125^{\star \star \star} \\
(0.017)\end{array}$ \\
\hline Hindu & $\begin{array}{l}0.017 \\
(0.020)\end{array}$ & $\begin{array}{l}-0.027 \\
(0.018)\end{array}$ & $\begin{array}{l}0.010 \\
(0.015)\end{array}$ & $\begin{array}{l}0.025 \\
(0.018)\end{array}$ & $\begin{array}{l}0.011 \\
(0.027)\end{array}$ & $\begin{array}{l}0.047^{\star * *} \\
(0.014)\end{array}$ \\
\hline Age of household head & $\begin{array}{l}0.070^{* * *} \\
(0.025)\end{array}$ & $\begin{array}{l}0.073^{\star * *} \\
(0.017)\end{array}$ & $\begin{array}{l}0.064^{* * *} \\
(0.018)\end{array}$ & $\begin{array}{l}0.094^{* * *} \\
(0.031)\end{array}$ & $\begin{array}{l}0.102^{* * *} \\
(0.030)\end{array}$ & $\begin{array}{l}0.106^{\star * *} \\
(0.023)\end{array}$ \\
\hline Constant & $\begin{array}{l}-0.486^{\star * *} \\
(0.164)\end{array}$ & $\begin{array}{l}-0.187 \\
(0.212)\end{array}$ & $\begin{array}{l}0.084 \\
(0.130)\end{array}$ & $\begin{array}{l}-1.041^{\text {*** }} \\
(0.178)\end{array}$ & $\begin{array}{l}-0.456^{* *} \\
(0.227)\end{array}$ & $\begin{array}{l}-0.640^{* * *} \\
(0.229)\end{array}$ \\
\hline $\begin{array}{l}\text { Observations } \\
R^{2}\end{array}$ & $\begin{array}{l}2308 \\
0.218\end{array}$ & $\begin{array}{l}4480 \\
0.219\end{array}$ & $\begin{array}{l}4419 \\
0.246\end{array}$ & $\begin{array}{l}1993 \\
0.248\end{array}$ & $\begin{array}{l}1657 \\
0.243\end{array}$ & $\begin{array}{l}2544 \\
0.232\end{array}$ \\
\hline
\end{tabular}

Note: Standard errors in parentheses. * ${ }^{* *}$, and ${ }^{* *}$ denote significance at 10,5 , and 1 per cent levels, respectively. District dummy variables are included.

Source: Authors' calculations using IHDS-II data.

Table 6: 3SLS estimates of log per capita expenditure

\begin{tabular}{|c|c|c|c|}
\hline & $\begin{array}{l}(1) \\
\text { All }\end{array}$ & $\begin{array}{l}(2) \\
\text { Rural }\end{array}$ & $\begin{array}{l}3) \\
\text { Urban }\end{array}$ \\
\hline Male household head & $\begin{array}{l}-0.059^{\star * *} \\
(0.013)\end{array}$ & $\begin{array}{l}-0.060^{* * *} \\
(0.016)\end{array}$ & $\begin{array}{l}-0.047^{* *} \\
(0.020)\end{array}$ \\
\hline Age of household head & $\begin{array}{l}0.381^{* \star \star} \\
(0.017)\end{array}$ & $\begin{array}{l}0.301^{\star \star \star} \\
(0.021)\end{array}$ & $\begin{array}{l}0.458^{\star * \star} \\
(0.030)\end{array}$ \\
\hline Years of education of household head & $\begin{array}{l}0.038^{* * *} \\
(0.001)\end{array}$ & $\begin{array}{l}0.028^{* * *} \\
(0.001)\end{array}$ & $\begin{array}{l}0.049^{* \star *} \\
(0.001)\end{array}$ \\
\hline Hindu & $\begin{array}{l}0.071^{\star \star *} \\
(0.011)\end{array}$ & $\begin{array}{l}0.073^{\star * *} \\
(0.015)\end{array}$ & $\begin{array}{l}0.035^{\star *} \\
(0.017)\end{array}$ \\
\hline SCST & $\begin{array}{l}-0.190^{\star * \star} \\
(0.011)\end{array}$ & $\begin{array}{l}-0.207^{\star * *} \\
(0.014)\end{array}$ & $\begin{array}{l}-0.126^{\star * *} \\
(0.018)\end{array}$ \\
\hline OBC & $\begin{array}{l}-0.087^{* * *} \\
(0.010)\end{array}$ & $\begin{array}{l}-0.079^{* * *} \\
(0.014)\end{array}$ & $\begin{array}{l}-0.080^{* * *} \\
(0.016)\end{array}$ \\
\hline Total number of adults & $\begin{array}{l}-0.064^{\star \star \star} \\
(0.003)\end{array}$ & $\begin{array}{l}-0.056^{\star \star *} \\
(0.004)\end{array}$ & $\begin{array}{l}-0.074^{\star * *} \\
(0.005)\end{array}$ \\
\hline Homeowner & $\begin{array}{l}-0.102^{\star \star \star} \\
(0.014)\end{array}$ & $\begin{array}{l}-0.016 \\
(0.032)\end{array}$ & $\begin{array}{l}-0.109^{* * *} \\
(0.016)\end{array}$ \\
\hline Electricity & $\begin{array}{l}0.188^{* * *} \\
(0.014)\end{array}$ & $\begin{array}{l}0.174^{\star \star *} \\
(0.015)\end{array}$ & $\begin{array}{l}0.246^{\star \star *} \\
(0.042)\end{array}$ \\
\hline Urban & $\begin{array}{l}0.165^{\star \star *} \\
(0.012)\end{array}$ & & \\
\hline Constant & $\begin{array}{l}8.832^{\star \star \star} \\
(0.084)\end{array}$ & $\begin{array}{l}9.146^{\star * *} \\
(0.104)\end{array}$ & $\begin{array}{l}8.481^{\star * *} \\
(0.150)\end{array}$ \\
\hline $\begin{array}{l}\text { Observations } \\
R^{2}\end{array}$ & $\begin{array}{l}17,603 \\
0.424\end{array}$ & $\begin{array}{l}11,323 \\
0.362\end{array}$ & $\begin{array}{l}6280 \\
0.408\end{array}$ \\
\hline
\end{tabular}

Note: Standard errors in parentheses. * ${ }^{* *}$, and ${ }^{* * *}$ denote significance at 10,5 , and 1 per cent levels, respectively. District dummy variables are included.

Source: Authors' calculations using IHDS-II data. 
Table 7: 3SLS estimates of budget share of educational expenditures

\begin{tabular}{|c|c|c|c|}
\hline & $\begin{array}{l}(1) \\
\text { All } \\
\end{array}$ & $\begin{array}{l}(2) \\
\text { Rural } \\
\end{array}$ & $\begin{array}{l}\text { (3) } \\
\text { Urban }\end{array}$ \\
\hline Female bargaining power & $\begin{array}{l}0.040^{* * *} \\
(0.012)\end{array}$ & $\begin{array}{l}-0.062^{\star * \star} \\
(0.021)\end{array}$ & $\begin{array}{l}0.115^{\star * \star} \\
(0.017)\end{array}$ \\
\hline $\begin{array}{l}\text { Female bargaining power }{ }^{2} \times \text { per capita } \\
\text { expenditure }\end{array}$ & $\begin{array}{l}-1.57 \mathrm{e}-07 \\
(1.85 \mathrm{e}-07)\end{array}$ & $\begin{array}{l}7.58 \mathrm{e}-07^{*} \\
(4.37 \mathrm{e}-07)\end{array}$ & $\begin{array}{l}-5.46 \mathrm{e}-07^{\star \star *} \\
(2.03 \mathrm{e}-07)\end{array}$ \\
\hline $\begin{array}{l}\text { Male bargaining power }{ }^{2} \times \text { per capita } \\
\text { expenditure }\end{array}$ & $\begin{array}{l}4.82 \mathrm{e}-07^{* * *} \\
(7.26 \mathrm{e}-08)\end{array}$ & $\begin{array}{l}-4.29 \mathrm{e}-08 \\
(1.30 \mathrm{e}-07)\end{array}$ & $\begin{array}{l}8.44 \mathrm{e}-07^{\star \star *} \\
(9.53 \mathrm{e}-08)\end{array}$ \\
\hline Urban & $\begin{array}{l}0.030^{* * *} \\
(0.002)\end{array}$ & & \\
\hline Log (household size) & $\begin{array}{l}0.013^{\star \star *} \\
(0.002)\end{array}$ & $\begin{array}{l}0.011^{* * *} \\
(0.002)\end{array}$ & $\begin{array}{l}0.012^{\star * *} \\
(0.004)\end{array}$ \\
\hline Share of males aged $0-4$ years & $\begin{array}{l}-0.081^{* \star *} \\
(0.012)\end{array}$ & $\begin{array}{l}-0.096^{* * *} \\
(0.013)\end{array}$ & $\begin{array}{l}-0.062^{* * *} \\
(0.024)\end{array}$ \\
\hline Share of females aged $0-4$ years & $\begin{array}{l}-0.078^{* * *} \\
(0.011)\end{array}$ & $\begin{array}{l}-0.083^{* * *} \\
(0.013)\end{array}$ & $\begin{array}{l}-0.083^{* * *} \\
(0.023)\end{array}$ \\
\hline Share of males aged 5-9 years & $\begin{array}{l}0.048^{\star \star \star} \\
(0.010)\end{array}$ & $\begin{array}{l}0.017 \\
(0.011)\end{array}$ & $\begin{array}{l}0.109^{* * *} \\
(0.019)\end{array}$ \\
\hline Share of females aged 5-9 years & $\begin{array}{l}0.031^{* \star *} \\
(0.010)\end{array}$ & $\begin{array}{l}0.013 \\
(0.011)\end{array}$ & $\begin{array}{l}0.063^{\star \star *} \\
(0.020)\end{array}$ \\
\hline Share of males aged $10-14$ years & $\begin{array}{l}0.071^{* * *} \\
(0.009)\end{array}$ & $\begin{array}{l}0.050^{* * *} \\
(0.010)\end{array}$ & $\begin{array}{l}0.111^{\star \star *} \\
(0.018)\end{array}$ \\
\hline Share of females aged $10-14$ years & $\begin{array}{l}0.050^{\star \star * *} \\
(0.009)\end{array}$ & $\begin{array}{l}0.027^{\star * *} \\
(0.010)\end{array}$ & $\begin{array}{l}0.098^{\star \star *} \\
(0.018)\end{array}$ \\
\hline Share of males aged $15-19$ years & $\begin{array}{l}0.083^{\star \star *} \\
(0.009)\end{array}$ & $\begin{array}{l}0.068^{\star * *} \\
(0.011)\end{array}$ & $\begin{array}{l}0.107^{\star * *} \\
(0.018)\end{array}$ \\
\hline Share of females aged $15-19$ years & $\begin{array}{l}0.062^{* * *} \\
(0.009)\end{array}$ & $\begin{array}{l}0.059^{* * *} \\
(0.010)\end{array}$ & $\begin{array}{l}0.092^{* * *} \\
(0.018)\end{array}$ \\
\hline Share of males aged $20-55$ years & $\begin{array}{l}-0.058^{* * *} \\
(0.011)\end{array}$ & $\begin{array}{l}-0.086^{* * *} \\
(0.015)\end{array}$ & $\begin{array}{l}-0.040^{* *} \\
(0.020)\end{array}$ \\
\hline Share of females aged $20-55$ years & $\begin{array}{l}-0.017^{\star *} \\
(0.008)\end{array}$ & $\begin{array}{l}0.004 \\
(0.009)\end{array}$ & $\begin{array}{l}-0.044^{* * *} \\
(0.016)\end{array}$ \\
\hline Share of males aged over 55 years & $\begin{array}{l}-0.056^{\star * *} \\
(0.013)\end{array}$ & $\begin{array}{l}-0.086^{* * *} \\
(0.015)\end{array}$ & $\begin{array}{l}-0.011 \\
(0.024)\end{array}$ \\
\hline Constant & $\begin{array}{l}-0.009 \\
(0.013)\end{array}$ & $\begin{array}{l}0.033^{* *} \\
(0.015)\end{array}$ & $\begin{array}{l}-0.027 \\
(0.025)\end{array}$ \\
\hline $\begin{array}{l}\text { Observations } \\
R^{2}\end{array}$ & $\begin{array}{l}17,603 \\
0.175\end{array}$ & $\begin{array}{l}11,323 \\
0.133\end{array}$ & $\begin{array}{l}6280 \\
0.134\end{array}$ \\
\hline \multicolumn{4}{|l|}{ Wald test for female bargaining power } \\
\hline$\theta=0$ & $69.24^{\star \star *}$ & $58.34^{\star * *}$ & $78.52^{\star * \star}$ \\
\hline$\theta=0.2$ & $34.36^{\star \star \star}$ & $109.34^{\star * \star}$ & $54.93^{* \star *}$ \\
\hline$\theta=0.4$ & $10.71^{* * *}$ & $125.23^{\star \star \star}$ & $52.43^{\star * \star}$ \\
\hline$\theta=0.6$ & $28.98^{* * *}$ & $92.93^{* * *}$ & $85.31^{* * *}$ \\
\hline$\theta=0.8$ & $51.65^{\star \star \star}$ & $65.67^{* * *}$ & $110.26^{\star * *}$ \\
\hline$\theta=1$ & $65.83^{\star * \star}$ & $49.71^{\star * *}$ & $121.66^{\star * *}$ \\
\hline Effect of female bargaining power & $0.021^{* *}$ & $-0.054^{\star * *}$ & $0.069^{* * *}$ \\
\hline$t$-Statistic & 2.48 & -4.01 & 5.84 \\
\hline
\end{tabular}

Note: Standard errors in parentheses. ${ }^{*},{ }^{* *}$, and ${ }^{* * *}$ denote significance at 10,5 , and 1 per cent levels, respectively. District dummy variables are included.

Source: Authors' calculations using IHDS-II data. 
Table 8: 3SLS estimates of budget share of educational expenditures by caste

\begin{tabular}{|c|c|c|c|c|c|c|}
\hline & (1) & (2) & (3) & $(4)$ & $(5)$ & (6) \\
\hline & \multicolumn{3}{|c|}{ Rural } & \multicolumn{3}{|c|}{ Urban } \\
\hline & $\begin{array}{l}\text { Upper } \\
\text { castes }\end{array}$ & SCSTS & OBCs & $\begin{array}{l}\text { Upper } \\
\text { castes }\end{array}$ & SCSTs & OBCs \\
\hline Female bargaining power & $\begin{array}{l}-0.021 \\
(0.041)\end{array}$ & $\begin{array}{l}0.036 \\
(0.029)\end{array}$ & $\begin{array}{l}-0.044 \\
(0.029)\end{array}$ & $\begin{array}{l}0.122^{\star * \star} \\
(0.032)\end{array}$ & $\begin{array}{l}0.129^{\star \star \star} \\
(0.024)\end{array}$ & $\begin{array}{l}0.077^{* * \star} \\
(0.029)\end{array}$ \\
\hline $\begin{array}{l}\text { Female bargaining power }{ }^{2} \times p e r \\
\text { capita expenditure }\end{array}$ & $\begin{array}{l}1.93 e-07 \\
(8.41 e-07)\end{array}$ & $\begin{array}{l}-3.96 \mathrm{e}-07 \\
(7.15 \mathrm{e}-07)\end{array}$ & $\begin{array}{l}5.11 e-07 \\
(5.84 e-07)\end{array}$ & $\begin{array}{l}-7.63 \mathrm{e}-07^{*} \\
(4.26 \mathrm{e}-07)\end{array}$ & $\begin{array}{l}-3.65 \mathrm{e}-07^{*} \\
(2.21 \mathrm{e}-07)\end{array}$ & $\begin{array}{l}-6.41 e-07^{\star} \\
(3.89 e-07)\end{array}$ \\
\hline $\begin{array}{l}\text { Male bargaining power }{ }^{2} \times \text { per capita } \\
\text { expenditure }\end{array}$ & $\begin{array}{l}-6.33 e-08 \\
(1.58 e-07)\end{array}$ & $\begin{array}{l}4.01 \mathrm{e}-07 \\
(2.65 \mathrm{e}-07)\end{array}$ & $\begin{array}{l}-1.27 \mathrm{e}-07 \\
(2.02 \mathrm{e}-07)\end{array}$ & $\begin{array}{l}7.08 \mathrm{e}-07^{* * *} \\
(1.65 \mathrm{e}-07)\end{array}$ & $\begin{array}{l}8.09 \mathrm{e}-07^{\star \star *} \\
(1.82 \mathrm{e}-07)\end{array}$ & $\begin{array}{l}4.84 \mathrm{e}-07^{\star \star *} \\
(1.45 \mathrm{e}-07)\end{array}$ \\
\hline Log (household size) & $\begin{array}{l}0.011^{* *} \\
(0.005)\end{array}$ & $\begin{array}{l}0.018^{* * *} \\
(0.003)\end{array}$ & $\begin{array}{l}0.013^{* * *} \\
(0.003)\end{array}$ & $\begin{array}{l}0.010 \\
(0.007)\end{array}$ & $\begin{array}{l}0.017^{* *} \\
(0.007)\end{array}$ & $\begin{array}{l}0.013^{* *} \\
(0.006)\end{array}$ \\
\hline Share of males aged $0-4$ years & $\begin{array}{l}-0.046 \\
(0.029)\end{array}$ & $\begin{array}{l}-0.061^{* * *} \\
(0.019)\end{array}$ & $\begin{array}{l}-0.089^{\star \star \star} \\
(0.020)\end{array}$ & $\begin{array}{l}-0.071 \\
(0.047)\end{array}$ & $\begin{array}{l}-0.015 \\
(0.039)\end{array}$ & $\begin{array}{l}-0.040 \\
(0.038)\end{array}$ \\
\hline Share of females aged $0-4$ years & $\begin{array}{l}-0.060^{* *} \\
(0.029)\end{array}$ & $\begin{array}{l}-0.041^{\star \star} \\
(0.018)\end{array}$ & $\begin{array}{l}-0.090^{\star \star \star} \\
(0.020)\end{array}$ & $\begin{array}{l}-0.133^{* * *} \\
(0.045)\end{array}$ & $\begin{array}{l}-0.035 \\
(0.039)\end{array}$ & $\begin{array}{l}-0.044 \\
(0.038)\end{array}$ \\
\hline Share of males aged $5-9$ years & $\begin{array}{l}0.018 \\
(0.025)\end{array}$ & $\begin{array}{l}0.041^{* *} \\
(0.017)\end{array}$ & $\begin{array}{l}0.031^{*} \\
(0.017)\end{array}$ & $\begin{array}{l}0.155^{\star * *} \\
(0.036)\end{array}$ & $\begin{array}{l}0.132^{\star \star \star} \\
(0.035)\end{array}$ & $\begin{array}{l}0.099^{* \star *} \\
(0.031)\end{array}$ \\
\hline Share of females aged $5-9$ years & $\begin{array}{l}0.048^{\star *} \\
(0.024)\end{array}$ & $\begin{array}{l}0.039^{\star *} \\
(0.017)\end{array}$ & $\begin{array}{l}0.006 \\
(0.017)\end{array}$ & $\begin{array}{l}0.096^{\star *} \\
(0.037)\end{array}$ & $\begin{array}{l}0.101^{* * *} \\
(0.035)\end{array}$ & $\begin{array}{l}0.042 \\
(0.030)\end{array}$ \\
\hline Share of males aged $10-14$ years & $\begin{array}{l}0.089^{* \star *} \\
(0.022)\end{array}$ & $\begin{array}{l}0.077^{\star \star *} \\
(0.015)\end{array}$ & $\begin{array}{l}0.044^{* * *} \\
(0.016)\end{array}$ & $\begin{array}{l}0.153^{\star * *} \\
(0.033)\end{array}$ & $\begin{array}{l}0.136^{\star \star *} \\
(0.032)\end{array}$ & $\begin{array}{l}0.115^{\star * *} \\
(0.029)\end{array}$ \\
\hline Share of females aged $10-14$ years & $\begin{array}{l}0.084^{\star * *} \\
(0.022)\end{array}$ & $\begin{array}{l}0.044^{\star * *} \\
(0.015)\end{array}$ & $\begin{array}{l}0.013 \\
(0.016)\end{array}$ & $\begin{array}{l}0.112^{* * *} \\
(0.032)\end{array}$ & $\begin{array}{l}0.082^{\star \star} \\
(0.032)\end{array}$ & $\begin{array}{l}0.131^{* * *} \\
(0.028)\end{array}$ \\
\hline Share of males aged $15-19$ years & $\begin{array}{l}0.123^{\star * *} \\
(0.023)\end{array}$ & $\begin{array}{l}0.095^{\star * *} \\
(0.017)\end{array}$ & $\begin{array}{l}0.062^{* \star *} \\
(0.016)\end{array}$ & $\begin{array}{l}0.167^{\star * *} \\
(0.033)\end{array}$ & $\begin{array}{l}0.116^{\star \star *} \\
(0.033)\end{array}$ & $\begin{array}{l}0.112^{\star * *} \\
(0.028)\end{array}$ \\
\hline Share of females aged $15-19$ years & $\begin{array}{l}0.083^{\star * *} \\
(0.022)\end{array}$ & $\begin{array}{l}0.071^{* * *} \\
(0.015)\end{array}$ & $\begin{array}{l}0.055^{\star * *} \\
(0.015)\end{array}$ & $\begin{array}{l}0.123^{\star * *} \\
(0.032)\end{array}$ & $\begin{array}{l}0.103^{\star \star *} \\
(0.031)\end{array}$ & $\begin{array}{l}0.104^{\star * *} \\
(0.029)\end{array}$ \\
\hline Share of males aged $20-55$ years & $\begin{array}{l}-0.034 \\
(0.029)\end{array}$ & $\begin{array}{l}-0.046^{* *} \\
(0.020)\end{array}$ & $\begin{array}{l}-0.079^{\star \star \star *} \\
(0.022)\end{array}$ & $\begin{array}{l}-0.063^{*} \\
(0.036)\end{array}$ & $\begin{array}{l}-0.022 \\
(0.034)\end{array}$ & $\begin{array}{l}-0.020 \\
(0.032)\end{array}$ \\
\hline Share of females aged $20-55$ years & $\begin{array}{l}0.013 \\
(0.020)\end{array}$ & $\begin{array}{l}0.009 \\
(0.015)\end{array}$ & $\begin{array}{l}-0.009 \\
(0.014)\end{array}$ & $\begin{array}{l}-0.054^{*} \\
(0.030)\end{array}$ & $\begin{array}{l}-0.039 \\
(0.028)\end{array}$ & $\begin{array}{l}-0.021 \\
(0.025)\end{array}$ \\
\hline Share of males aged over 55 years & $\begin{array}{c}-0.039 \\
(0.031)\end{array}$ & $\begin{array}{l}-0.071^{\star * *} \\
(0.021)\end{array}$ & $\begin{array}{l}-0.084^{\star * \star} \\
(0.022)\end{array}$ & $\begin{array}{l}-0.006 \\
(0.043)\end{array}$ & $\begin{array}{l}0.046 \\
(0.043)\end{array}$ & $\begin{array}{l}-0.030 \\
(0.039)\end{array}$ \\
\hline Constant & $\begin{array}{c}-0.002 \\
(0.027)\end{array}$ & $\begin{array}{l}0.107^{\star *} \\
(0.047)\end{array}$ & $\begin{array}{l}0.034 \\
(0.023)\end{array}$ & $\begin{array}{l}-0.018 \\
(0.040)\end{array}$ & $\begin{array}{l}-0.065 \\
(0.055)\end{array}$ & $\begin{array}{l}-0.027 \\
(0.063)\end{array}$ \\
\hline $\begin{array}{l}\text { Observations } \\
R^{2}\end{array}$ & $\begin{array}{l}2308 \\
0.255\end{array}$ & $\begin{array}{l}4480 \\
0.217\end{array}$ & $\begin{array}{l}4419 \\
0.167\end{array}$ & $\begin{array}{l}1993 \\
0.233\end{array}$ & $\begin{array}{l}1657 \\
0.206\end{array}$ & $\begin{array}{l}2544 \\
0.216\end{array}$ \\
\hline Wald test for female bargaining pow & & & & & & \\
\hline$\theta=0$ & 0.27 & 2.41 & $8.09^{* *}$ & $19.22^{\star \star \star}$ & $29.61^{\star * *}$ & $11.06^{\star \star \star}$ \\
\hline$\theta=0.2$ & 0.92 & 1.66 & $15.46^{\star \star *}$ & $14.75^{\star \star *}$ & $29.86^{* * *}$ & $8.39^{* *}$ \\
\hline$\theta=0.4$ & 2.28 & $5.01^{*}$ & $19.65^{\star \star \star}$ & $19.47^{\star \star \star}$ & $35.59^{* * *}$ & $7.18^{\star *}$ \\
\hline$\theta=0.6$ & 2.63 & $8.8^{* *}$ & $17.01^{* * *}$ & $33.06^{\star * *}$ & $44.37^{* * *}$ & $9.08^{* *}$ \\
\hline$\theta=0.8$ & 2.49 & $9.95^{\star * *}$ & $13.55^{\star * *}$ & $39.15^{\text {*** }}$ & $47.60^{\star * *}$ & $10.89^{* * *}$ \\
\hline$\theta=1$ & 2.32 & $10.08^{* * *}$ & $11.14^{\star * *}$ & $40.43^{\star * *}$ & $47.30^{\star * *}$ & $11.94^{* * *}$ \\
\hline $\begin{array}{l}\text { Effect of female bargaining power } \\
t \text {-Statistic }\end{array}$ & $\begin{array}{l}-0.017 \\
-0.57\end{array}$ & $\begin{array}{l}0.023 \\
1.32\end{array}$ & $\begin{array}{l}-0.036^{*} \\
-1.94\end{array}$ & $\begin{array}{l}0.074^{\star \star *} \\
3.37\end{array}$ & $\begin{array}{l}0.091^{\star \star *} \\
5.30\end{array}$ & $\begin{array}{l}0.05^{\star *} \\
2.34\end{array}$ \\
\hline
\end{tabular}

Note: Standard errors in parentheses. * **, and ${ }^{* *}$ denote significance at 10,5 , and 1 per cent levels, respectively. District dummy variables are included.

Source: Authors' calculations using IHDS-II data. 
Table 9: Difference in marginal effects between girls and boys by age, caste, and location

\begin{tabular}{|c|c|c|c|c|c|c|c|c|c|}
\hline \multirow{3}{*}{$\begin{array}{l}\text { Age } \\
\text { (years) }\end{array}$} & (1) & (2) & (3) & (4) & (5) & (6) & (7) & (8) & (9) \\
\hline & All & Rural & Urban & \multicolumn{3}{|c|}{ Rural } & \multicolumn{3}{|c|}{ Urban } \\
\hline & & & & UCs & SCSTs & OBCs & UCs & SCSTs & OBCs \\
\hline $5-9$ & $\begin{array}{l}-0.017^{* *} \\
(0.008)\end{array}$ & $\begin{array}{l}-0.004 \\
(0.008)\end{array}$ & $\begin{array}{l}-0.045^{\star * *} \\
(0.015)\end{array}$ & $\begin{array}{l}0.029 \\
(0.019)\end{array}$ & $\begin{array}{l}-0.002 \\
(0.012)\end{array}$ & $\begin{array}{l}-0.025^{*} \\
(0.013)\end{array}$ & $\begin{array}{l}-0.059^{* *} \\
(0.029)\end{array}$ & $\begin{array}{l}-0.031 \\
(0.026)\end{array}$ & $\begin{array}{l}-0.057^{\text {** }} \\
(0.023)\end{array}$ \\
\hline $10-14$ & 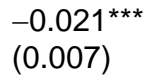 & $\begin{array}{l}-0.023^{\star \star \star} \\
(0.008)\end{array}$ & $\begin{array}{l}-0.013 \\
(0.013)\end{array}$ & $\begin{array}{l}-0.005 \\
(0.017)\end{array}$ & $\begin{array}{l}-0.033^{* * *} \\
(0.012)\end{array}$ & $\begin{array}{l}-0.031^{\star *} \\
(0.012)\end{array}$ & $\begin{array}{l}-0.041 \\
(0.025)\end{array}$ & $\begin{array}{l}-0.054^{\star *} \\
(0.023)\end{array}$ & $\begin{array}{l}0.016 \\
(0.02)\end{array}$ \\
\hline $15-19$ & $\begin{array}{l}-0.024^{* \star *} \\
(0.007)\end{array}$ & $\begin{array}{l}-0.012 \\
(0.008) \\
\end{array}$ & $\begin{array}{r}-0.015 \\
(0.013) \\
\end{array}$ & $\begin{array}{l}-0.039^{* *} \\
(0.018)\end{array}$ & $\begin{array}{l}-0.024^{*} \\
(0.013)\end{array}$ & $\begin{array}{c}-0.007 \\
(0.012) \\
\end{array}$ & $\begin{array}{l}-0.044^{*} \\
(0.024)\end{array}$ & $\begin{array}{r}-0.013 \\
(0.023) \\
\end{array}$ & $\begin{array}{l}-0.008 \\
(0.02)\end{array}$ \\
\hline
\end{tabular}

Note: UCs, upper castes. Difference between marginal effects is measured as female minus male such that negative values indicate pro-male bias. Standard errors in parentheses. ${ }^{*},{ }^{* *}$, and ${ }^{* * *}$ denote significance at 10,5 , and 1 per cent levels, respectively.

Source: Authors' calculations using IHDS-II data.

Table 10: 3SLS Estimates of budget share of educational expenditures by sex

\begin{tabular}{|c|c|c|c|c|c|c|}
\hline & (1) & (2) & (3) & (4) & (5) & (6) \\
\hline & \multicolumn{2}{|c|}{ All } & \multicolumn{2}{|c|}{ Rural } & \multicolumn{2}{|c|}{ Urban } \\
\hline & Girls & Boys & Girls & Boys & Girls & Boys \\
\hline Female bargaining power & $\begin{array}{l}0.028^{\star \star *} \\
(0.010)\end{array}$ & $\begin{array}{l}-0.007 \\
(0.013)\end{array}$ & $\begin{array}{l}-0.092^{* * *} \\
(0.021)\end{array}$ & $\begin{array}{l}-0.014 \\
(0.016)\end{array}$ & $\begin{array}{l}0.111^{\star \star *} \\
(0.015)\end{array}$ & $\begin{array}{l}-0.021 \\
(0.021)\end{array}$ \\
\hline $\begin{array}{l}\text { Female bargaining power }{ }^{2} \times \text { per } \\
\text { capita expenditure }\end{array}$ & $\begin{array}{l}-1.45 e-07 \\
(1.53 e-07)\end{array}$ & $\begin{array}{l}3.13 e-07 \\
(2.39 e-07)\end{array}$ & $\begin{array}{l}1.36 \mathrm{e}-06^{* *} \\
(5.38 \mathrm{e}-07)\end{array}$ & $\begin{array}{l}2.55 e-07 \\
(3.42 e-07)\end{array}$ & $\begin{array}{l}-5.97 \mathrm{e}-07^{* * *} \\
(1.65 \mathrm{e}-07)\end{array}$ & $\begin{array}{l}6.22 \mathrm{e}-07^{*} \\
(3.33 \mathrm{e}-07)\end{array}$ \\
\hline $\begin{array}{l}\text { Male bargaining power }{ }^{2} \times p e r \\
\text { capita expenditure }\end{array}$ & $\begin{array}{l}3.19 \mathrm{e}-07^{\star \star *} \\
(6.50 \mathrm{e}-08)\end{array}$ & $\begin{array}{l}2.67 \mathrm{e}-07^{\star \star *} \\
(7.55 \mathrm{e}-08)\end{array}$ & $\begin{array}{l}-1.34 \mathrm{e}-07 \\
(1.23 \mathrm{e}-07)\end{array}$ & $\begin{array}{l}7.52 \mathrm{e}-08 \\
(1.20 \mathrm{e}-07)\end{array}$ & $\begin{array}{l}6.31 e-07^{\star \star \star} \\
(9.13 e-08)\end{array}$ & $\begin{array}{l}3.31 e-07^{* \star *} \\
(9.73 e-08)\end{array}$ \\
\hline Log (household size) & $\begin{array}{l}0.008^{* * *} \\
(0.002)\end{array}$ & $\begin{array}{l}0.004^{* *} \\
(0.002)\end{array}$ & $\begin{array}{l}0.005^{\star * *} \\
(0.002)\end{array}$ & $\begin{array}{l}0.007^{* * *} \\
(0.002)\end{array}$ & $\begin{array}{l}0.009^{* *} \\
(0.004)\end{array}$ & $\begin{array}{l}-0.000 \\
(0.004)\end{array}$ \\
\hline Constant & $\begin{array}{l}0.006 \\
(0.012)\end{array}$ & $\begin{array}{l}0.017 \\
(0.013)\end{array}$ & $\begin{array}{l}0.049^{\star \star *} \\
(0.015)\end{array}$ & $\begin{array}{l}0.014 \\
(0.014)\end{array}$ & $\begin{array}{l}-0.033 \\
(0.024)\end{array}$ & $\begin{array}{l}0.050^{*} \\
(0.027)\end{array}$ \\
\hline $\begin{array}{l}\text { Observations } \\
R^{2}\end{array}$ & $\begin{array}{l}12,090 \\
0.186\end{array}$ & $\begin{array}{l}13,126 \\
0.179\end{array}$ & $\begin{array}{l}7902 \\
0.0548\end{array}$ & $\begin{array}{l}8531 \\
0.154\end{array}$ & $\begin{array}{l}4188 \\
0.137\end{array}$ & $\begin{array}{l}4595 \\
0.189\end{array}$ \\
\hline \multicolumn{7}{|l|}{ Wald test for female bargaining } \\
\hline$\theta=0$ & $31.77^{* \star *}$ & $71.59^{\star \star *}$ & $86.89^{\star \star \star}$ & $15.16^{\star \star \star}$ & $59.94^{\star \star \star}$ & $47.56^{\star \star \star}$ \\
\hline$\theta=0.2$ & $18.02^{* * *}$ & $54.28^{* \star *}$ & $219.61^{* * *}$ & $17.19^{\star * *}$ & $56.24^{\star \star *}$ & $35.31^{* * *}$ \\
\hline$\theta=0.4$ & $7.33^{* *}$ & $15.35^{\star \star \star}$ & $295.90^{* * *}$ & $11.76^{\star \star \star}$ & $66.19^{\star \star \star}$ & $9.03^{* *}$ \\
\hline$\theta=0.6$ & $13.97^{* * *}$ & 0.37 & $236.70^{\star * *}$ & $4.91^{*}$ & $85.40^{* * *}$ & 1.11 \\
\hline$\theta=0.8$ & $23.30^{\star * *}$ & 3.83 & $179.47^{\star * \star}$ & 1.97 & $94.19^{\star * \star}$ & $5.16^{\star}$ \\
\hline$\theta=1$ & $29.23^{* * *}$ & $9.72^{* * *}$ & $144.40^{* * *}$ & 1.03 & $95.91^{* * *}$ & $9.87^{* * *}$ \\
\hline Effect of female bargaining power & $0.015^{\star *}$ & -0.014 & $-0.078^{* * *}$ & -0.015 & $0.076^{\star \star *}$ & $-0.032^{* *}$ \\
\hline$t$-Statistic & 2.14 & -1.59 & -5.69 & -1.37 & 7.12 & -2.18 \\
\hline
\end{tabular}

Note: Standard errors in parentheses. * ${ }^{* *}$, and ${ }^{* *}$ denote significance at 10,5 , and 1 per cent levels, respectively. Age-sex composition variables and district dummy variables are included.

Source: Authors' calculations using IHDS-II data. 
Table 11: 3SLS Estimates of budget share of educational expenditures by sex and caste in RURAL areas

\begin{tabular}{|c|c|c|c|c|c|c|}
\hline & $(1)$ & (2) & (3) & $(4)$ & $(5)$ & (6) \\
\hline & \multicolumn{2}{|c|}{ Upper castes } & \multicolumn{2}{|c|}{ SCSTs } & \multicolumn{2}{|c|}{ OBCs } \\
\hline & Girls & Boys & Girls & Boys & Girls & Boys \\
\hline Female bargaining power & $\begin{array}{l}-0.031 \\
(0.035)\end{array}$ & $\begin{array}{l}0.026 \\
(0.029)\end{array}$ & $\begin{array}{l}0.003 \\
(0.032)\end{array}$ & $\begin{array}{l}0.022 \\
(0.022)\end{array}$ & $\begin{array}{l}-0.078^{* * *} \\
(0.023)\end{array}$ & $\begin{array}{l}-0.020 \\
(0.025)\end{array}$ \\
\hline $\begin{array}{l}\text { Female bargaining power }{ }^{2} \times \text { per capita } \\
\text { expenditure }\end{array}$ & $\begin{array}{l}0.000 \\
(0.000)\end{array}$ & $\begin{array}{l}-0.000 \\
(0.000)\end{array}$ & $\begin{array}{l}-0.000 \\
(0.000)\end{array}$ & $\begin{array}{l}-0.000 \\
(0.000)\end{array}$ & $\begin{array}{l}0.000^{\star \star *} \\
(0.000)\end{array}$ & $\begin{array}{l}0.000 \\
(0.000)\end{array}$ \\
\hline Male bargaining power ${ }^{2} \times$ per capita expenditure & $\begin{array}{l}-0.000 \\
(0.000)\end{array}$ & $\begin{array}{l}0.000 \\
(0.000)\end{array}$ & $\begin{array}{l}0.000 \\
(0.000)\end{array}$ & $\begin{array}{l}0.000^{*} \\
(0.000)\end{array}$ & $\begin{array}{l}-0.000 \\
(0.000)\end{array}$ & $\begin{array}{l}-0.000 \\
(0.000)\end{array}$ \\
\hline Log (household size) & $\begin{array}{l}0.008^{\star *} \\
(0.004)\end{array}$ & $\begin{array}{l}0.005 \\
(0.005)\end{array}$ & $\begin{array}{l}0.012^{\star \star \star} \\
(0.003)\end{array}$ & $\begin{array}{l}0.010^{* * *} \\
(0.003)\end{array}$ & $\begin{array}{l}0.005^{\star} \\
(0.003)\end{array}$ & $\begin{array}{l}0.007^{* *} \\
(0.003)\end{array}$ \\
\hline Constant & $\begin{array}{l}0.018 \\
(0.022)\end{array}$ & $\begin{array}{l}-0.008 \\
(0.026)\end{array}$ & $\begin{array}{l}0.180^{* \star *} \\
(0.045)\end{array}$ & $\begin{array}{l}0.057 \\
(0.054)\end{array}$ & $\begin{array}{l}0.059 * * * \\
(0.021)\end{array}$ & $\begin{array}{l}0.018 \\
(0.021)\end{array}$ \\
\hline $\begin{array}{l}\text { Observations } \\
R^{2}\end{array}$ & $\begin{array}{l}1569 \\
0.262\end{array}$ & $\begin{array}{l}1718 \\
0.274\end{array}$ & $\begin{array}{l}3176 \\
0.250\end{array}$ & $\begin{array}{l}3367 \\
0.182\end{array}$ & $\begin{array}{l}3084 \\
0.147\end{array}$ & $\begin{array}{l}1569 \\
0.262\end{array}$ \\
\hline Wald test for female bargaining power & & & & & & \\
\hline$\theta=0$ & 0.89 & 1.85 & 0.05 & $5.57^{*}$ & $34.96^{\star * *}$ & 0.73 \\
\hline$\theta=0.2$ & 4.53 & 1.28 & 0.13 & 2.41 & $48.03^{\star * *}$ & 2.17 \\
\hline$\theta=0.4$ & $9.36^{\star * *}$ & 0.81 & 0.95 & 1.31 & $46.41^{\star * *}$ & $4.80^{*}$ \\
\hline$\theta=0.6$ & $9.80^{\star * \star}$ & 1.23 & 1.50 & $4.95^{\star}$ & $29.75^{\star \star \star}$ & $5.99^{\star *}$ \\
\hline$\theta=0.8$ & $9.11^{* *}$ & 1.68 & 1.58 & $7.73^{\star *}$ & $19.89^{* * *}$ & $6.08^{\star \star}$ \\
\hline$\theta=1$ & $8.47^{* \star}$ & 1.92 & 1.54 & $9.01^{* *}$ & $15.60^{\star \star \star}$ & $5.87^{\star}$ \\
\hline Effect of female bargaining power & -0.026 & 0.015 & 0.0007 & 0.011 & $-0.059^{\star \star *}$ & -0.016 \\
\hline$t$-Statistic & -1.024 & 0.748 & 0.035 & 0.808 & -4.28 & -0.98 \\
\hline
\end{tabular}

Note: Standard errors in parentheses. * ${ }^{* *}$, and ${ }^{* *}$ denote significance at 10,5 , and 1 per cent levels, respectively. Age-sex composition variables and district dummy variables are included.

Source: Authors' calculations using IHDS-II data. 
Table 12: 3SLS Estimates of budget share of educational expenditures by sex and caste in urban areas

\begin{tabular}{|c|c|c|c|c|c|c|}
\hline & $(1)$ & (2) & (3) & (4) & $(5)$ & (6) \\
\hline & \multicolumn{2}{|c|}{ Upper castes } & \multicolumn{2}{|c|}{ SCSTs } & \multicolumn{2}{|c|}{ OBCs } \\
\hline & Girls & Boys & Girls & Boys & Girls & Boys \\
\hline Female bargaining power & $\begin{array}{l}0.075^{\star \star} \\
(0.029)\end{array}$ & $\begin{array}{l}0.066^{\star *} \\
(0.033)\end{array}$ & $\begin{array}{l}0.092^{\star \star \star} \\
(0.024)\end{array}$ & $\begin{array}{l}0.026 \\
(0.029)\end{array}$ & $\begin{array}{l}0.089^{* * *} \\
(0.024)\end{array}$ & $\begin{array}{l}-0.098^{* *} \\
(0.046)\end{array}$ \\
\hline $\begin{array}{l}\text { Female bargaining power }{ }^{2} \times \text { per capita } \\
\text { expenditure }\end{array}$ & $\begin{array}{l}-0.000 \\
(0.000)\end{array}$ & $\begin{array}{l}-0.000 \\
(0.000)\end{array}$ & $\begin{array}{l}-0.000 \\
(0.000)\end{array}$ & $\begin{array}{l}0.000 \\
(0.000)\end{array}$ & $\begin{array}{l}-0.000^{* * *} \\
(0.000)\end{array}$ & $\begin{array}{l}0.000 \\
(0.000)\end{array}$ \\
\hline $\begin{array}{l}\text { Male bargaining power }{ }^{2} \times \text { per capita } \\
\text { expenditure }\end{array}$ & $\begin{array}{l}0.000^{* *} \\
(0.000)\end{array}$ & $\begin{array}{l}0.000^{* * *} \\
(0.000)\end{array}$ & $\begin{array}{l}0.000^{* \star *} \\
(0.000)\end{array}$ & $\begin{array}{l}0.000 \\
(0.000)\end{array}$ & $\begin{array}{l}0.000^{*} \\
(0.000)\end{array}$ & $\begin{array}{l}0.000 \\
(0.000)\end{array}$ \\
\hline Log (household size) & $\begin{array}{l}0.001 \\
(0.007)\end{array}$ & $\begin{array}{l}0.007 \\
(0.008)\end{array}$ & $\begin{array}{l}0.021^{\star \star *} \\
(0.007)\end{array}$ & $\begin{array}{l}-0.003 \\
(0.006)\end{array}$ & $\begin{array}{l}0.005 \\
(0.006)\end{array}$ & $\begin{array}{l}0.000 \\
(0.006)\end{array}$ \\
\hline Constant & $\begin{array}{l}0.008 \\
(0.039)\end{array}$ & $\begin{array}{l}0.035 \\
(0.043)\end{array}$ & $\begin{array}{l}-0.060 \\
(0.071)\end{array}$ & $\begin{array}{l}0.002 \\
(0.047)\end{array}$ & $\begin{array}{l}-0.028 \\
(0.051)\end{array}$ & $\begin{array}{l}0.052 \\
(0.075)\end{array}$ \\
\hline $\begin{array}{l}\text { Observations } \\
R^{2}\end{array}$ & $\begin{array}{l}1273 \\
0.321\end{array}$ & $\begin{array}{l}1425 \\
0.281\end{array}$ & $\begin{array}{l}1145 \\
0.256\end{array}$ & $\begin{array}{l}1209 \\
0.303\end{array}$ & $\begin{array}{l}1715 \\
0.232\end{array}$ & $\begin{array}{l}1273 \\
0.321\end{array}$ \\
\hline \multicolumn{7}{|l|}{ Wald test for female bargaining power } \\
\hline$\theta=0$ & $7.44^{* *}$ & $14.63^{* \star *}$ & $16.17^{\star \star \star}$ & 1.18 & $16.01^{* * \star}$ & $13.24^{* * \star}$ \\
\hline$\theta=0.2$ & $6.62^{* *}$ & $8.22^{* *}$ & $14.85^{\star \star *}$ & 0.92 & $18.36^{\star \star \star}$ & $27.76^{\star * \star}$ \\
\hline$\theta=0.4$ & $10.03^{\star * *}$ & 4.27 & $14.87^{\star \star *}$ & 3.61 & $20.65^{\star \star \star}$ & $31.06^{\star \star \star}$ \\
\hline$\theta=0.6$ & $15.36^{\star * \star}$ & $11.31^{* \star *}$ & $18.32^{\star * \star}$ & $6.28^{* *}$ & $20.12^{* \star *}$ & $23.24^{* * *}$ \\
\hline$\theta=0.8$ & $16.79^{\star \star \star}$ & $18.03^{\star \star \star}$ & $21.71^{\star \star \star}$ & $7.06^{\star \star}$ & $18.59^{\star \star \star}$ & $17.80^{* * *}$ \\
\hline$\theta=1$ & $16.64^{\star * *}$ & $21.22^{\star \star \star}$ & $22.99^{\star \star \star}$ & $7.12^{\star *}$ & $17.47^{\star \star \star}$ & $14.72^{\star \star \star}$ \\
\hline Effect of female bargaining power & $0.049^{\star \star}$ & 0.028 & $0.058^{\star \star *}$ & 0.018 & $0.073^{\star \star \star}$ & $-0.088^{* * *}$ \\
\hline$t$-Statistic & 2.41 & 1.22 & 3.39 & 0.88 & 4.07 & -2.64 \\
\hline
\end{tabular}

Note: Standard errors in parentheses. * ${ }^{* *}$, and ${ }^{* *}$ denote significance at 10,5 , and 1 per cent levels, respectively. Age-sex composition variables and district dummy variables are included.

Source: Authors' calculations using IHDS-II data. 


\section{Appendix A: OLS results}

Table A1: OLS estimates of female bargaining power

\begin{tabular}{|c|c|c|c|}
\hline & $\begin{array}{l}\text { (1) } \\
\text { All }\end{array}$ & $\begin{array}{l}(2) \\
\text { Rural } \\
\end{array}$ & $\begin{array}{l}(3) \\
\text { Urban }\end{array}$ \\
\hline Share of female education in total education & $\begin{array}{l}-0.197^{\star \star \star} \\
(0.021)\end{array}$ & $\begin{array}{l}-0.145^{\star \star \star} \\
(0.026)\end{array}$ & $\begin{array}{l}-0.325^{\star \star *} \\
(0.040)\end{array}$ \\
\hline Share of female education squared & $\begin{array}{l}0.472^{* * *} \\
(0.023)\end{array}$ & $\begin{array}{l}0.397^{* * *} \\
(0.027)\end{array}$ & $\begin{array}{l}0.664^{\star \star *} \\
(0.042)\end{array}$ \\
\hline Log (total expenditure) & $\begin{array}{l}0.008^{*} \\
(0.004)\end{array}$ & $\begin{array}{l}-0.009^{\star} \\
(0.006)\end{array}$ & $\begin{array}{l}0.034^{\star * *} \\
(0.007)\end{array}$ \\
\hline Log (household size) & $\begin{array}{l}-0.087^{* \star *} \\
(0.007)\end{array}$ & $\begin{array}{l}-0.073^{\star * *} \\
(0.009)\end{array}$ & 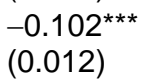 \\
\hline Hindu & $\begin{array}{l}0.025^{* * *} \\
(0.006)\end{array}$ & $\begin{array}{l}0.008 \\
(0.009)\end{array}$ & $\begin{array}{l}0.033^{* * *} \\
(0.010)\end{array}$ \\
\hline SCST & $\begin{array}{l}0.024^{\star \star *} \\
(0.006)\end{array}$ & $\begin{array}{l}0.042^{* \star *} \\
(0.008)\end{array}$ & $\begin{array}{l}-0.003 \\
(0.010)\end{array}$ \\
\hline $\mathrm{OBC}$ & $\begin{array}{l}0.008 \\
(0.006)\end{array}$ & $\begin{array}{l}0.026^{* * *} \\
(0.008)\end{array}$ & $\begin{array}{l}-0.011 \\
(0.009)\end{array}$ \\
\hline Age of household head & $\begin{array}{l}0.081^{\star * *} \\
(0.009)\end{array}$ & $\begin{array}{l}0.070^{\star * *} \\
(0.011)\end{array}$ & $\begin{array}{l}0.104^{\star * \star} \\
(0.016)\end{array}$ \\
\hline Urban & $\begin{array}{l}-0.048^{\star * *} \\
(0.007)\end{array}$ & & \\
\hline Constant & $\begin{array}{l}-0.203^{* * *} \\
(0.063)\end{array}$ & $\begin{array}{l}-0.000 \\
(0.079)\end{array}$ & $\begin{array}{l}-0.551^{* * *} \\
0.108)\end{array}$ \\
\hline $\begin{array}{l}\text { Observations } \\
R^{2}\end{array}$ & $\begin{array}{l}17,603 \\
0.181\end{array}$ & $\begin{array}{l}11,323 \\
0.194 \\
\end{array}$ & $\begin{array}{l}6280 \\
0.180\end{array}$ \\
\hline
\end{tabular}

Note: Standard errors in parentheses. * ${ }^{* *}$, and ${ }^{* * *}$ denote significance at 10,5 , and 1 per cent levels, respectively. District dummy variables are included.

Source: Authors' calculations using India Human Development Survey 2011-12 (IHDS-II) data.

Table A2: OLS estimates of log per capita expenditure

\begin{tabular}{|c|c|c|c|}
\hline & $\begin{array}{l}(1) \\
\text { All }\end{array}$ & $\begin{array}{l}(2) \\
\text { Rural } \\
\end{array}$ & $\begin{array}{l}\text { (3) } \\
\text { Urban }\end{array}$ \\
\hline Male household head & $\begin{array}{l}-0.050^{\star \star \star} \\
(0.013)\end{array}$ & $\begin{array}{l}-0.052^{\star \star \star} \\
(0.016)\end{array}$ & $\begin{array}{l}-0.040^{*} \\
(0.021)\end{array}$ \\
\hline Age of household head & $\begin{array}{l}0.378^{* * *} \\
(0.018)\end{array}$ & $\begin{array}{l}0.299^{\star * *} \\
(0.021)\end{array}$ & $\begin{array}{l}0.456^{\star * \star} \\
(0.031)\end{array}$ \\
\hline Years of education of household head & $\begin{array}{l}0.037^{\star * *} \\
(0.001)\end{array}$ & $\begin{array}{l}0.028^{\star \star \star} \\
(0.001)\end{array}$ & $\begin{array}{l}0.047^{\star \star \star} \\
(0.001)\end{array}$ \\
\hline Hindu & $\begin{array}{l}0.069^{\star * *} \\
(0.011)\end{array}$ & $\begin{array}{l}0.072^{\star \star *} \\
(0.015)\end{array}$ & $\begin{array}{l}0.032^{*} \\
(0.017)\end{array}$ \\
\hline SCST & $\begin{array}{l}-0.187^{\star \star *} \\
(0.011)\end{array}$ & $\begin{array}{l}-0.207^{\star \star *} \\
(0.014)\end{array}$ & $\begin{array}{l}-0.120^{\star \star \star} \\
(0.018)\end{array}$ \\
\hline OBC & $\begin{array}{l}-0.086^{* * *} \\
(0.011)\end{array}$ & $\begin{array}{l}-0.079^{* * \star} \\
(0.014)\end{array}$ & $\begin{array}{l}-0.077^{\text {** }} \\
(0.016)\end{array}$ \\
\hline Total number of adults & $\begin{array}{l}-0.064^{\star \star *} \\
(0.003)\end{array}$ & $\begin{array}{l}-0.056^{* * *} \\
(0.004)\end{array}$ & $\begin{array}{l}-0.074^{\star * *} \\
(0.005)\end{array}$ \\
\hline Homeowner & $\begin{array}{l}-0.103^{* * *} \\
(0.014)\end{array}$ & $\begin{array}{l}-0.016 \\
(0.033)\end{array}$ & $\begin{array}{l}-0.112^{\star \star \star} \\
(0.016)\end{array}$ \\
\hline Electricity & $\begin{array}{l}0.186^{\star * \star} \\
(0.014)\end{array}$ & $\begin{array}{l}0.173^{\star \star *} \\
(0.015)\end{array}$ & $\begin{array}{l}0.243^{\star * \star} \\
(0.043)\end{array}$ \\
\hline Urban & $\begin{array}{l}0.168^{\star \star \star *} \\
(0.012)\end{array}$ & & \\
\hline Constant & $\begin{array}{l}8.845^{\star \star *} \\
(0.085)\end{array}$ & $\begin{array}{l}9.149^{\star \star *} \\
(0.106)\end{array}$ & $\begin{array}{l}8.501^{* * *} \\
(0.154)\end{array}$ \\
\hline $\begin{array}{l}\text { Observations } \\
R^{2}\end{array}$ & $\begin{array}{l}17,603 \\
0.424\end{array}$ & $\begin{array}{l}11,323 \\
0.362\end{array}$ & $\begin{array}{l}6280 \\
0.408\end{array}$ \\
\hline
\end{tabular}

Note: Standard errors in parentheses. * **, and ${ }^{* \star *}$ denote significance at 10, 5, and 1 per cent levels, respectively. District dummy variables are included.

Source: Authors' calculations using IHDS-II data. 